Ondokuz Mayıs Üniversitesi İlahiyat Fakültesi Dergisi,

Ondokuz Mayss University Review of the Faculty of Divinity

e-ISSN: 2587-1854 OMUIFD, June 2021, 50: 237-276

\title{
SAMSUN FOLKLORUNDA ÖLÜM VE KOVID-19 SALGINI
}

\author{
DEATH AND COVID-19 PANDEMIC IN \\ SAMSUN FOLKLORE
}

\section{ÖMER SARAÇ}

[Dr. Öğr. Üyesi. Ondokuz Mayıs Üniversitesi, Türk Dili ve Edebiyatı Ana Bilim Dalı, Türk Halk Edebiyatı Faculty Member PhD. Ondokuz Mayıs University, Department of Turkish Language and Literature omer.sarac@omu.edu.tr http://orcid.org/ 0000-0001-8005-7370]

\author{
Makale Bilgisi / Article Information \\ Makale Türü / Article Types: Araştırma Makalesi / Research Article \\ Geliş Tarihi / Received: 25 Mart / March 2021 \\ Kabul Tarihi / Accepted: 13 Nisan /April 2021 \\ Yayın Tarihi / Published: 24 Haziran / June 2021 \\ Yayın Sezonu / Pub Date Season: Haziran / June \\ Yll/Year: $2021 \quad$ Sayı-Issue: $50 \quad$ Sayfa/Pages: 237-276
}

Atıf/Cite as Saraç, Ömer. "Samsun Folklorunda Ölüm ve Kovid-19 Salgını-Death and Covid19 Pandemic in Samsun Folklore". Ondokuz Mayıs Üniversitesi İlahiyat Fakültesi DergisiOndokuz Mayıs University Review of the Faculty of Divinity 50 (Haziran-June 2021): 237276. https://doi.org/10.17120/omuifd.903272

İntihal /Plagiarism: Bu makale, en az iki hakem tarafından incelendi ve intihal içermediği teyit edildi. / This article has been reviewed by at least two referees and scanned via a plagiarism software. http://dergipark.gov.tr/omuifd

Copyright (C) Published by Ondokuz Mayıs Üniversitesi, İlahiyat Fakültesi - Ondokuz Mayıs University, Faculty of Divinity, Samsun, Turkey. All rights reserved. 


\section{Samsun Folklorunda Ölüm ve Kovid-19 Salgını}

Öz: Anadolu insanının geleneksel yaşamının ve davranış kalıplarının özünü oluşturan birçok âdet, inanma ve ritüel mevcuttur. İnsan yaşamında üç önemli geçiş evresi vardır. Bunlar; doğum, evlenme ve ölümdür. Bu dönemlerin her birinde farklı âdet, inanma, tören, dinsel ve büyüsel işlemler gözlemlenmektedir. Bu işlemlerin birçoğu insanın yeni durumuna uyum sağlaması temelinde gerçekleştirilmektedir. Ölüm, dünya hayatının son bulması anlamını taşımaktadır. Bu nedenle insanlar için her zaman gizemli bir durum arz etmiştir. İnsanlı̆̆ın var oluşundan günümüze kadar uzanan süreçte ölümün uzaklaştırılması amacıyla birçok ritüel ve pratik uygulanagelmiştir. Samsun yöresinde görülen pek çok ritüel, uygulama ve inanış, Anadolu'nun diğer yöreleriyle benzerlik göstermektedir ve bunların çoğu geçmiş inanışlardan da izler taşımaktadır. Çalışmanın bir diğer yönünü de günümüzde tüm dünyayı etkisi alan Yeni Tip Koronavirüs (Kovid-19) sonrası ölüm âdet ve uygulamalarında görülen değişim oluşturmaktadır. Bu salgın sürecinin insanları çaresiz kıldığı ve ölümle ilgili geleneklerde ciddi evrilmelere neden olduğu muhakkaktır. Çünkü geleneğin oluşumuna veya evirilmesine insanlar arasındaki ilişkiler yön vermektedir. Dolayısıyla bu süreç Türk kültür tarihi açısından da önemli bir milattır. Bu çalışmada Samsun yöresindeki ölüm âdetleri değerlendirilmiş ve tümevarım yöntemi salgının bu âdetler üzerine yaptığı etki araştırma konusu edilmiştir.

Anahtar Sözcükler: Samsun, folklor, ölüm, Yeni Tip Koronavirüs (Kovid-19), değişim

\section{繂}

\section{Death and Covid-19 Pandemic in Samsun Folklore}

Abstract: There are many customs, beliefs and rituals that constitute the core of thetraditional life and behaviour patterns of Anatolian people. There are three important transition stages in human life. These are birth, marriage and death. Different customs, beliefs, ceremonies, religious and magical processes are observed in each of these periods. Many of these processes are carried out on the basis of human adaptation to the new situation. Death has always been a mysterious situation for people because it means the end of life in the world. In the process from the existence of humanity to the presentday, a large number of rituals and practices have been applied in order to send death away. Many rituals, practices and beliefs seen in Samsun region are similar to other regions in Anatolia and most of them beartraces of past beliefs. Another aspect of the study is to reveal the changes seen in death customs and practices after the novel Coronavirus (COVID19) which has affected the whole world. It is certain that this epidemic process made people desperate and caused serious changes in our traditions related with death because relations between people guide the formation orevolution of traditions. Therefore, this process is also an important miles- 
tone in terms of Turkish cultural history. The present study evaluates death customs and discusses the effects the pandemic has caused on these customs. In addition, inductive method has been used in the study.

Keywords: Samsun, Folklore, Death, Novel Coronavirus (COVID-19), Change.

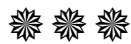

\section{Giriş}

Ölüm, insanoğlunun var oluşundan itibaren tüm insanlar için dikkat çekici bir konu olmuştur. Çoğu zaman ölümden kurtulmak ya da ölümü geciktirmek için birtakım çareler aranmış; bazen de ölümün kendisi bizzat kurtuluş olmuştur. Şemsettin Samî, Kamus-i Türkî'de ölüm kavramını şu şekilde tanımlar: "Yaşamaz olmak, can vermek, terk-i hayat etmek, vefat, irtihal etmek, fevt olmak, solmak, yumuşamak, pejmurde olmak, kıvamı gaib edip düşmek, pek ziyade sıkılmak, pek şiddetli korku veya dehşet ve ızdırap ve zahmet çekmek, hükmü kalmamak"1. Ayrıca ölüm, vadenin dolması, ruhun bedenden ayrılması sonucunda vücudun canlıl1ğını kaybetmesi ya da ruhun vücuttan ayrılması durumu olarak değerlendirilmiştir. ${ }^{2}$

Eski Türkçe döneminde öl- fiili ve türevleri ile karşılanan ölüm kavramı için 61 sözcük bulunmaktadır. ${ }^{3} \mathrm{Bu}$ kadar çok kelimenin kullanılmasını insanların ölüm ve ötesi ile ilgili düşüncelerinin zengin bir tezahürü olarak değerlendirmek yerinde olacaktır. Sosyal bir varlık olan insan bir yakını ya da tanıdığını kaybettiğinde derin bir üzüntü duyar. Sonuçta ne kadar üzülürse üzülsün ölüm olgusunun değişmeyeceğini bilir. Ölüme çare bulamayan birey, ölüm karşısındaki tavrını farklı yollarla ortaya koymaya çalışır. Bu bazen bir ağıt, bazen bir türkü, bazen bir beddua gibi halk biliminin farklı bir türü olarak karşımıza çıkar.

Şemseddin Sami, Kâmûs-1 Türkî,( İstanbul: Çağrı Yayınları,2009), 223.

2 Türkçe Sözlük (Ankara: Türk Dil Kurumu Yay. 1983); Joseph Campbell, Illkel Mitoloji, Çev. Kudret Emiroğlu, (Ankara: İmge Kitabevi,1992), 132;, Hacer Tokyürek. “Eski Uygur Türkçesinde "Ölüm" Kavramı ile İlgili İfadeler", Bilig Dergisi 50 (2009), 178-181;ìbrahim Kafesoğlu, Eski Türk Dini, (Ankara: Kültür Bakanlığı Yayınları, 1980), 47.

3 Yıldız Kocasavaş “Türkçe'nin Tarihî Dönemlerinde Ölüm Kavramının İfadesi”, İstanbul Üniversitesi Edebiyat Fakültesi Türk Dili ve Edebiyatı Dergisi, 29, (2000), 77-115. 
Yog, yogçı, yoğlamak kelimeleri Türklerin en eski yazılı metni olan Orhon Yazıtları'nda geçen ölümle ilgili kelimelerdir. Bilge Kağan'ın ağzından yazılmış olan Kül Tigin Abidesi'nde, onun koyun yılının on yedisinde öldüğü, dokuzuncu ayın yirmi yedisinde yog töreni yapıldı̆̆ından bahsedilmektedir.4 Divânü Lügat-it-Türk'te Yog/Yuğ kavramı "Ölü gömüldükten sonra üç yahut yedi güne kadar verilen yemek."5 olarak ifade edilmektedir. Eski Türklerde ölünün ardından pek çok uygulama ve ritüelin yerine getirildiğini ifade edebiliriz. "Göktürkler ölünün ardından büyük yog (yas) töreni ve ayinler yaparlardı. MS 739'da Türk hükümdarlarından Kürsul Han'ın ölümü münasebetiyle yapılan defin ve yas töreni Tabarani'de şöyle tavsif edilmiştir: Eski Türkler ölünün hatırasına büyük aş (ziyafet) törenleri yaparlar, zenginler yüzlerce hayvan keserlerdi. Hazırlanan yemeklerden bir kısmın ölünün mezarı üzerine dökerlerdi. ${ }^{6}$ Yine Eski Türklerde ölüm sonrasında yapılan pratikler ve cenaze yakınlarının takındıkları

240 tavrı Abdülkadir İnan şu şekilde ifade etmektedir: "Göktürkler ölüyü çadıra

OMÜIFD koyarlar. Ölenin akrabaları atları, koyunları keserler ve çadırın önüne sererler. Ölü bulunan çadırın etrafinda at üzerinde yedi defa dolaşırlar. Kapının önünde bıçakla yüzlerini kesip ağlarlar."7 Günümüzde ölü aşı olarak karşılanan yoğ aşı Kutadgu Bilig'de şöyle ifade edilmektedir: "Bu ay Toldınıng kıldı oglıyagı / Çıgayka üledi kümüş hem agı (Oğlu Ay-Toldı için ölüm aşı yaptı / Fakirlere gümüş ve ipekli kumaşlar dağıttı)"8

Türk kültür tarihinin başyapıtlarından olan Dede Korkut Kitabı'nın Mukaddime bölümünde yer alan "Ezelden yazılmasa kul başına kaza gelmez, ecel $v a$ 'de irmeyince kimse ölmez. Ölen adam dirilmez, çıkan can girü gelmez"9 biçimindeki ifadelerden, Oğuzlarda İslam inancına uygun bir kader anlayışının bulunduğu ve ölüm karşısında dolaylı olarak mütevekkil olmanın öğütlendiği anlaşılmaktadır. Ayrıca burada kullanılan ezel, kul, kaza,

\footnotetext{
Muharrem Ergin, Orhun Abideleri, (İstanbul: Boğaziçi Yayınları, 2012), 28.

Besim Atalay, Divânü Lügât-it-Türk, 3, (Ankara: TDK Yayınları,1998), 143.

Abdülkadir İnan, Eski Türk Dini Tarihi, (İstanbul: Milli Eğitim Basımevi,1976),183.

Abdülkadir İnan, Tarihte ve Bugün Şamanizm Materyaller ve Araştırmalar, (Ankara: Türk Tarih Kurumu Yayınları, 2015) ,177.

8 Reşit Rahmeti Arat, Kutadgu Bilig I- Metin, (Ankara: TDK Yayınları,1991), 173.

9 Muharrem Ergin, Dede Korkut Kitabı-1 (Ankara: TDK Yayınları, 2008), 73.
} 
ecel, va'de, ölmek ve dirilmek gibi kavramlardan anlaşıldığına göre burada, insanın yaratılmadan önce kaderinin belirlendiğine işaret edilmekte; hayat, ölüm ve ölüm sonrası ahiret inanışıyla ilgili kronolojik bilgiler öğretici bir üslupla dile getirilmektedir. ${ }^{10}$

İnsanoğlu; doğa olaylarının, bazı varlıkların veya çeşitli nesnelerin ölümle ilişkili olduğunu düşündüğünden bu varlık ve nesneler karşısında birtakım önlemler alma ya da bunlardan korunma ihtiyacı hissetmiştir. Bunun neticesinde de birtakım inanma, pratik ya da ritüellerin ortaya çıkması doğaldır. Ölüm, hayatın geçiş dönemlerinden biri olmakla birlikte insan zihnini, insanın hayatı algılamasını en çok etkileyen bir olay olmuştur. Kur'an-1 Kerim'de "Her nefis ölümü tadacaktır."11 ayeti ile açık bir şekilde beyan edildiği gibi ölüm kaçınılmaz bir sondur. İnsanoğlunun ölüm karşısında yaşadığı yoğun duygular, onu ölümü anlamaya ve anlamlandırmaya yöneltmiştir.

Anadolu'nun pek çok yöresinde olduğu gibi Samsun'da da ölümle ilgili birçok inanma ve ritüelden söz etmek mümkündür. Bu inanma ve ritüeller ölüm öncesi, sırası ve sonrası olmak üzere üç ana başlık altında değerlendirilecektir.

\section{1. Ölüm Öncesi}

\section{1. Ölümü Düşündüren Ön Belirtiler}

Dede Korkut Kitabı'nda yer alan Salur Kazan'ın Evinin Yağmalandığı Hikâyede, Salur Kazan "saçının kargı gibi uzandığını ve gözünü örttüğünü" rüyasında görür. Bunun üzerine rüyayı yorumlayan Kazan'ın kardeşi Kara Göne ise saçın kaygı anlamı taşıdığını belirtir.12 Anadolu'nun pek çok yöresinde rüyada saç görmek iyiye yorumlanmaz ve saça olumsuz anlam yüklenir.

10 Bekir Şişman, Samsun Yöresinde Yaşayan Halk İnançları Üzerine Bir İnceleme, (Samsun: Ondokuz Mayıs Üniversitesi, Sosyal Bilimler Enstitüsü, Yüksek Lisans Tezi, 1994), 124.

11 Enbiyâ, 21/35.

12 Ergin, Dede Korkut Kitab1-1, 100. 
Samsun yöresinde kişinin biyolojik durumu, tabiat olayları, gök cisimlerinin hareketleri, hayvanların hareketlerinde görülen farklı durumlar ya da çeşitli nesneler ölümü düşündüren/hatırlatan belirtiler olarak değerlendirilmektedir. "Ölüm korkusunun bilinçaltındaki baskısıyla tedirgin olan halk düşüncesi, geleceği bilmek isteğinin de etkisiyle, alışılagelmişin dışındaki birtakım davranışları; araç gereçlerin şu ya da bu biçimdeki kullanılışını; meteorolojik olayları; hayvanların hareket ve seslerini; düşlerdeki görüntülerle hastadaki psikolojik ve fizyolojik değişiklikleri çoğu zaman ölümün bir işareti, bir önbelirtisi saymaktadır."13

Özellikle evin çatısında öten baykuş ve köpek uluması yörede bilinen en yaygın belirtilerdendir. Bunun dışnda gök cisimlerinin hareketleri ve kişide görülen bazı tavırlar ölüm emaresi olarak kabul edilmektedir. Şişman'ın, Gölalan Mahallesi'nde gök cisimleri ile ilgili tespit ettiği örnek dikkat çekicidir: "Mahallede hasta varken yıldızlar grup halinde kayarsa

242 o hasta ölecek demektir."14 Özdemir de Havza'nın Karga Mahallesi'nde OMÜiFD ölümün ön belirtisi olarak şunu tespit etmiştir: "Ölen şahsın boynu eğri ise arkasından biri ölecek inancı halk arasında yaygındır."15 Salıpazarı ilçesinde kişinin üzerinde elbise dikmenin ömrü kısaltacağına dair inanış söz konusudur. Bu nedenle düğme dikmek için bile olsa gömleğin çıkartılması ölümü uzaklaştırmak amacıyla yapılan uygulamalardandır. Ayrıca gece tırnak kesmenin de ömrü kısalttığına dair inanışlar özellikle elli yaş üzerindeki insanlarda görülmektedir. Çok fazla şimşek çakıp yağmur yağarsa sevilen birisinin öleceği düşünülür. Yağmurun çok fazla yağmasına, ölen kişinin ardından gökyüzünün ağladığı biçiminde yorum yap1lır. Ölümü beklenen kişinin vücudunun soğuması da ölümün ön belirtisi olarak değerlendirilir. Yine aynı yörede rüyada dişlerin çıktığı veya döküldügü görülürse rüyayı gören kişinin bir yakının öleceği düşünülür. (K 5) Ondokuz Mayıs ilçesinde bir karganın evin bacasına yuva yapması ve

13 Sedat Veyis Örnek, Anadolu Folklorunda Ölüm (Ankara: Ankara Üniversitesi Dil Tarih Coğrafya Fakültesi Yayınları,1971), 15.

14 Şişman, Samsun Yöresinde Yaşayan Halk İnançlar Üzerine Bir İnceleme, 73.

15 Emrah Özdemir, Samsun İli Havza İlçesi Karga Köyü Monografisi, (Ankara: Gazi Üniversitesi, Sosyal Bilimler Enstitüsü, Yüksek Lisans Tezi, 2008), 227. 
orada ötmesi ölümü çağırdığına işarettir. Yine horozun zamansız ötmesi ve köpeğin uluması da ölümün ön belirtisi olarak yorumlanır. (K 9) Bafra ilçesinde köpeğin sela okunurken uluması uğursuzluk sayılır ve evin yakınından uzaklaştıılması gerekir. Aksi takdirde o evden ölü çıkar. (K 14) Çarşamba ilçesinde göz seğirmesi ölüme yorulur. Sağ göz seğirirse yakından, sol göz seğirirse uzaktan birinin öleceğine inanılır. Ölmek üzere olan bir kişi aniden çok yemek yemeye başlarsa "Rızkını topluyor" denilir ve o kişinin öleceği düşünülür. Bebek sebepsiz yere ağlıyorsa o evden ölü çıkacak demektir. 1990'lı yıllarda yaşanmış bir olay şöyledir: Yeni doğmuş bir bebek karnı tok olduğu ve herhangi bir hastalığı olmadığı halde sebepsiz yere sürekli ağlıyormuş. Birkaç ay sonra bebeğin babası ölmüş ve bu olaydan sonra bebeğin ağlamaları kesilmiş. Bu durum bebeğin, babasının öleceğini hissettiği şeklinde yorumlanmıştır. (K 1) Bafra ilçesinde bir kişinin ayakkabısı sürekli olarak ters dönüyorsa o kişinin ölümünün yaklaştığı düşünülür. Rüyada cenaze, tabut, mezar ya da mezarlık görülürse o evden ölü çıkacak demektir. (K 19) Vezirköprü merkezde atların huysuzlanıp tepinmesi birinin öleceğini düşündürür. Yine yıldız kayması da birinin öleceğine işarettir. Vezirköprü'nün Nalbantlı Mahallesinden Orta Cami'ye çıkan yokuşta kişi üç kez durup dinlenirse o kişinin öleceğine inanılır. Rüyada görülen bulanık su da ölümün ön belirtisi olarak değerlendirilmektedir. (K 10) Havza ilçesinde kişinin vücut azalarından bir kısmının, özellikle ayakların şişmesi, burnunun üstünün beyazlaşması, burun kıllarının örümceklenmesi, burnunun uzaması, boynunun düşmesi, gözlerinin bulutlanması ve kulağının arkasının ağarması ölümün ön belirtisi şeklinde ifade edilmektedir. ${ }^{16}$ Yine aynı yörede rüyada evin yıkılması da bir olumsuzluk yaşanacağına işarettir. Eğer ev içeri doğru yıkılırsa yakın akrabalardan, dışarıya doğru yıkılırsa da akraba dışından birinin öleceğine yorulur. Lâdik ilçesinde ölecek kişinin burnu düşer, gözleri tavana dikilidir ve o kişi sürekli havaya bakar. Ayrıca iştahı olmaz, konuşamaz, oturamaz ve boynu düşer. Başını güçlükle de olsa havaya kaldıramaz. (K 12) İlkadım ilçesi Çivril

16 Cafer Özdemir, Havza İlçesinin Genel Folklorik Yapısı, Uluslararası Sosyal Araştırma Dergisi, 2/7, (2009), 194. 
Mahallesi'nde uzun süredir hasta olan bir hastanın aniden iyileşmesi de o kişinin öleceğinin ön belirtisi olarak düşünülür. Yine aynı mahallede hamile bir kişinin saçını kesmesi o kişinin çocuğunun öleceğine ya da ömrünün kısa olacağına delalettir. (K 16) Atakum ilçesine bağlı Taflan yöresinde evin bacasında baykuş ötmesi/dolaşması o evden ölü çıkacağına işarettir. (K 13) Kavak'ta bir kişinin rüyasında evinin duvarının yıkılması yakında o kişinin ölümünün gerçekleşeceğine yorulur. Ayrıca yere düşen tabağın kırılmaması da hayra yorulmaz. Uğursuzluk getireceği düşünülerek o tabak tekrar yere atılarak kırılır. (K 18) Samsun merkeze bağlı Demircisu (Başkonak) Mahallesi'nde bir kişi borcunu, alacağını söylerse ölümü yaklaşmış demektir. Canik ilçesinde makasın ağzının açık kalması ölümün habercisi sayılır. Ağzı açık makasın kefen biçeceği düşünülür. Ayakkabı, terlik ters çevrilirse evden ölü çıkacağına inanılır. Bu nedenle ters dönen bu nesneler hemen düzeltilir. (K 6) İlkadım ilçesine bağlı Yu-

244 karıavdan Mahallesi'nde bir kişi rüyasında ölmüş birini gördükten sonra ölü o evden herhangi bir şey alıp giderse o evden ölü çıkacağı düşünülür. Yine aynı mahallede rüyada kazma kürek görmek iyiye yorulmaz. Bir kişinin tarlasından aldığı ürün her zamankinden fazla olursa o kişinin öleceğine işarettir. Samsun merkezde yürüyebilen çocuk emeklerse o evden ya da yakın komşulardan birinin öleceği düşünülür. Asarcık ilçesinde bir kişi rüyasında bir kadını anadan üryan görürse erkek cenazesi, erkeği anadan üryan görürse bir kadın cenazesi çıkacağına inanılır. Rüyada ölüye bir şey vermek iyiye yorulmaz. Kısa zaman içinde ölüm olacağına inanılır. Hasta olan kişinin bakışlarında kaymalar ve teninde sararmalar olursa bu durum o kişinin yakında öleceğine işarettir. (K 3) Alaçam'da rüyada kara kazan görmek ölüm habercisi olarak değerlendirilir. Rüyada ayakkabının tekini giyip tekini bulamamak rüyayı gören kişinin eşinin öleceğine yorulur. Yine aynı yörede kötü rüyanın anlatılması iyiye yorulmaz. Bu tür rüyalar bir başka kişiye anlatılırsa ölüm getirir düşüncesi hâkimdir. Evde pişirilen ilk ekmeği yiyen kişinin eşinin öleceğine dair inanış vardır. Bu nedenle ilk ekmek çocuğa ya da bekâr birine yedirilmektedir. Yörede söylenen "bebekler uyuya uyuya büyür, yaşlılar uyuya uyuya ölür" sözü, çok uyuyan yaşlılar için ölümünün yakın olduğu 
biçiminde yorumların yapılmasına neden olmaktadır. Rüyada ölmüş birinden ikram almak da ölümün habercisi olarak değerlendirilir. Mezar kazma işinde kullanılan kazma ve kürek eve sokulmaz. Aksi takdirde ölüm getirir düşüncesi yaygındır. (K 20)

\section{2. Ölümden Kaçınmalar}

Ölüm, insanoğlu için kaçınılmaz bir sondur. Ancak yine de ölümün soğuk yüzünden kaçınmak amacıyla birtakım uygulama ve pratiklerin yapıldığı bilinen bir gerçektir. "Ölümü hatırlatan, ölüm için ön belirti olan rüyaların psikolojik ve fizyolojik değişikliklerin yanında yerine getirilmediği zaman ölüm getireceğine inanılan birtakım inanışlar ve davranışlar da bulunmaktadır."17

Yukarıavdan Mahallesi'nde araçla mezarlığın yanından geçerken ölülerin ruhlarını rahatsız etmemek için müziğin sesi kapatılır. Yine mezarlıktan geçerken kabrin elle gösterilmesi hoş karşılanmaz. Cenazenin defninden sonra mezarlıktan ayrılırken geri bakılmaz. (K 17) Bafra'da cenaze işlemleri sırasında ölü yıkandıktan sonra teneşir ters çevrilir. Ölüm gerçekleştiği anda ölünün gözleri kapatılır. Eğer kapatılmazsa yakınındaki kişileri de peşinden götürmek istediği şeklinde yorumlanır. Mezarlıktan ağaç kesilmez. Eğer kesilirse felaketlerin geleceğine inanılır. Gece tırnak kesmenin ömrü kısaltacağı ve ölümü çağıracağı düşünülür. Aynı şekilde gece aynaya bakmanın da ömrü kısaltacağı şeklinde düşünceler söz konusudur. (K 14) Alaçam ilçesinde geçmişte cenaze yıkamak için kullanılan kazan yeni bir ölüm olayının olmaması amacıyla ters çevrilir ya da kazanın ağzını kapatmak için iki uzun odun konulurdu. Yine aynı yörede kazandaki suyu isıtmak için kullanılan ateş, su ile söndürülmez; ateşin kendiliğinden sönmesi beklenirdi. (K 20)

\section{2. Ölüm Sırası}

Ölüm olayının en dramatik anı şüphesiz ölüm sırasıdır. İster genç ister yaşlı olsun ölüm, herkesi derinden etkilemektedir. Ölümün gerçekleşmesi

17 Örnek, Anadolu Folklorunda Ölüm,37. 
ile birlikte birtakım dinî vecibelerin yerine getirilmesine başlanır. Bu vecibeler İslamî usullere göre şekillenir.

\section{1. Ölüm Anı}

İnsanoğlu için kaçınılmaz bir olgu olan ölüm, kişinin son nefesini vermesi ile gerçekleşir. Ölümün gerçekleştiği vücudun soğuması ve morarmasından anlaşılır. Ölümün vaki olması ile birlikte bazı uygulama ve pratikler kendini göstermeye başlar. Öncelikli olarak ölü hemen hemen tüm yörede "rahat yatağı" adı verilen yere yatırılır. Ölen kişinin üzerine genellikle beyaz bir çarşaf örtülür ve üzerine bıçak ya da makas gibi demir türü bir nesne konulur. Bunun yapılmasındaki amaç cenazenin şişmesine engel olmaktır. Çarşamba ilçesinde cinsiyet belirli olsun diye makas kadın, bıçak ise erkek cenazenin üzerine konulur. Hasta gözlerini kapatır, elleri yana düşer, son olarak da derin bir nefes alıp verir. Bu şekilde ruhunu teslim eder. Öleceği anlaşılan hastaya "can çekişiyor", "can veriyor" denmektedir. Öldükten sonra ise öldü demek yerine "ruhunu teslim etti" şeklinde ifadeler kullanılır. Ölüye "cenaze", "mevta" denilir. Ölünün çıktığ1 eve "cenaze evi" ya da "ölü evi" denilmektedir. (K 1) Bafra ve Salıpazarı ilçelerinde cenazenin üzerinden hayvan atlamaması için ölünün üzerine ağ gerilir. (K 14, 7) Vezirköprü'de can çekişerek ölen kişinin günahının çok olduğu söylenir. Ruhunu rahat bir şekilde teslim edenlerinse günahsız olduğuna ve Cennet'e gideceğine inanılır. Hasta ölmek üzereyken eğer konuşabiliyorsa son bir sözü veya vasiyeti olup olmadığı öğrenilmeye çalışılır. Eğer vasiyeti varsa dinlenir. Hasta, gözleri açı ölürse gözleri kapatılır. Eğer ölünün gözleri kapanmıyorsa "dünyaya hasret gitti" şeklinde yorumlar yapılır. (K 10) Canik ilçesinde eğer ölen kişinin gözleri kapanmıyorsa sağ ayağının başparmağı çekilirse gözlerinin kapanacağına dair inanış vardır. Ölen kişinin ağzında takma dişleri varsa mutlaka çıkarılır. Ölen kadınsa kolunda, boynunda ve kulağında bulanan takılar da çıkarılarak alınır. Ölen kişi peşinden başka birini daha götürmesin diye ölünün yanına soğuk bir taş konulur ve cenaze yıkamaya götürülene kadar o taş yanında kalır. Ayrıca odaya kedi köpek gibi hayvanların girmemesine dikkat edilir. Hastanın kesin olarak öldüğüne ka- 
naat getirilirse beden sertleşmeden üzerindeki elbiseler çıkarılır. Elbiseler çıkarıldıktan sonra ölen kişi sert bir zemine yatırılır ve elleri yan tarafta olacak şekilde düz bir biçime sokulur. ${ }^{18}$ Canik ilçesinde can çekişen hastanın yanında yüksek sesle ağlamak ve çı̆̆lık atmak hoş görülmez. Bu durumda ölen kişinin ruhunun geri geleceği düşüncesi hâkimdir. Yine aynı yörede ruhunu teslim edemeyen hastanın uzakta olan bir yakınını beklediği söylenir ve o kişinin gömleği ya da ceketi ölecek kişinin üzerine atılır. Böylece kolay bir şekilde can verebileceği düşünülür. Kızıloğlak Mahallesi'nde bu şekilde bir kişinin ruhunu teslim ettiği ifade edilmiştir. Hasta canını veremiyorsa ve dargın olduğu bir kişi varsa o kişinin eli yıkanır ve o su ölüm döşeğindeki hastaya içirilirse rahat bir şekilde ruhunu teslim edeceği düşünülür. Ölen kişinin eti çok yumuşaksa peşinden başka bir ölüm daha gerçekleşecek demektir. (K 6) Atakum/Taflan'da ölünün üzerindeki elbiseler makasla kesilerek çıkarılır. Ölen kişiden hatıra kalması için elbiseden bir parça alıp saklamak gelenek halini almıştır. (K 13) Ondokuz Mayıs ilçesinde ise ölünün üzerindeki elbisenin makasla kesilerek alınmasının nedeni ölen kişinin canının elbisesinin üzerinde olduğu düşüncesidir. Hemen tüm ilçelerde ölmek üzere olan hastanın yanında hasta ölürken söylemeyi unutmasın diye hatırlatma amacıyla devamlı olarak kelime-i şehadet getirilir. Hastanın kesin olarak ölüp ölmediğini anlamak için mümkünse doktor çağrılır. Eğer doktor yoksa hastanın son nefesini verip vermediğini anlamak için hastanın ağzına ayna tutulur. Eğer ayna buharlaşırsa hasta ölmemiş, buharlaşmamışsa ölmüştür. Ölünün ağzının açık kalması hoş karşılanmaz. Bu nedenle çirkin görünmesi diye bir bez yardımıyla ölünün çenesi bağlanır. Ayak başparmakları birbirine bağlanır. (K 9) Alaçam ilçesinde hasta eğer gözlerini bir yere diktiğinde yüzü gülüyorsa Cennet'i, üzgün halde duruyorsa Cehennem'i görüyor demektir. Yine aynı yörede gurbetteki yakını nedeniyle gözleri açık öldüğüne inanılan kişinin gözleri “Benim elim değil, hasretliğinin eli diyerek" gözleri sıvazlanarak kapatılır. Hastanın öleceği anlaşıl-

18 Filiz Sönmez, Samsun İli Canik İlçesi Geçiş Dönemi Âdetlerinde Görülen Kültürel Değişimler, (Samsun: Ondokuz Mayıs Üniversitesi, Sosyal Bilimler Enstitüsü, Yüksek Lisans Tezi, 2019), 79-80. 
dığında, başında eğer yakınlarından Kur'an okumayı bilen kişi varsa o kişi Kur'an okur, yoksa hoca çağrılır. Ölmek üzere olan hastanın ağzına sürekli su verilir, su içemeyecek durumda ise dudakları pamuk yardımıyla sslatılır. Hastanın canı ilk olarak ayak kısmından çıkmaya başlar. (K 20) Terme'de genç ölümlerinde ya da hiç beklenmedik bir yaşta ölen kişi olduğunda "Allah bizden daha çok seviyormuş, yanına aldı" denir. (K 11) Lâdik ilçesinde gözü açık ölene "Dünyaya hasret gitti." denir. Ölüm gerçekleştiğinde etrafındaki kişiler onu en son haliyle hatırlayacakları için ölünün vücudu düzgün duracak şekle sokulmaya çalışılır. Ölü doğan bebeğin Cennet'e gideceğine inanılır. Cenaze erkek ise başında erkek, bayan ise bayan bekler. Ölümün gerçekleşmesinden sonra başı değil ayakları kıbleye çevrilir. Çünkü ölü daha temizlenmemiş olduğundan kutsal olarak kabul edilen kıbleye başının çevrilmesi uygun görülmez. (K 12) Asarcık ilçesinde sağlığında cömert olan kişilerin ölüm anında kolay

248 can verebileceğine inanılır. Ölecek kişinin bulunduğu odada ağlamak hoş OMÜiFD görülmez. Bu nedenle odada derin bir sessizlik hâkimdir. Ölüm sırasında odada bulunanlar ölecek kişinin ayakucundan kalkarak baş tarafında toplanırlar. (K 2) Ayvacık ve Lâdik'te ölüm döşeğinde olan hastanın kolay can verebilmesi için ağzına zemzem suyu verilir. $(K 4,12)$ Atakum'da eğer ölecek kişinin yüzü terliyorsa islak bir bezle temizlenir. (K 13) İlkadım ilçesi Çivril Mahallesi'nde ölen kadınsa çarşafın üzerine elbiselik konulur. (K 16) Canik ilçesine bağlı Demircisu Mahallesi'nde uzun süre can çekişen kişinin üzerine incir yaprağı konulur, beklediği tahmin edilen kişinin geldiği söylenir. Böylece can çekişen kişinin canını kolayca teslim etmesi sağlanır. Yine uzun süre can çekişen kişi için ya düzelmesi ya da ruhunu teslim edebilmesi adına kırk bir Yasin okutulur. İster merkez ister diğer ilçelerde olsun ölecek kişinin baş ucunda Yasin suresinin okunmasi/okutulması vazgeçilmez uygulamalardan biridir. Ölüm döşeğinde olan kişinin yanında sürekli bir kişi bulunur, oda hiç boş bırakılmaz. Ölüm yazın gerçekleşmişse cenazenin kokmaması için pencereler açlır. (K 6) Lâdik ilçesinde ölen kişinin elbiseleri yıkanır ve fakirlere dağıtılır. (K 12) Pek çok ilçede olduğu gibi Ayvacık'ta da ağıt yakma geleneği vardır. Bu ağıtlarda genellikle ölünün yaptığı iyiliklerden ve güzel huylarından 
bahsedilir. Ağıt sadece sözle değil belli bir ezgiyle söylenir. Yas tutma ikinci olarak giyim kuşamda kendini gösterir. Cenazesi olan ev halkı genellikle koyu renk ağırlıklı elbiseler giyer. Uzun bir süre yeni elbise giymedikleri gibi gösterişli giysiler giymekten de kaçınırlar. Cenaze günü giydikleri elbiseleri birkaç gün üzerlerinden çıkarmazlar. Yine uzunca bir süre hamama gitmemek, evde televizyon izlememek, düğünlerde oynamamak ve yüksek sesle gülmemek yas âdeti olarak görülmektedir. Yakın komşuların da yas âdetlerine uydukları görülür. (K 4) Diğer ilçelerden farklı olarak Bafra ilçesinin mahallelerinde cenazenin saçına ve eline kına yakma âdeti vardır. (K 14) Ondokuz Mayıs ilçesi yörüklerinde ölümün gerçekleştiği günden itibaren üç gün boyunca komşular tarafından ölü evine yemekler getirilir. Ölü evinde üç gün yemek pişmez. (K 9)

\section{2. Ölümün Duyurulması}

Samsun yöresinde ölümün duyurulması genellikle camiden "sela" verilerek ve hoparlörden duyuru yapılarak yerine getirilir. Ölen kişinin kim olduğu, cenaze namazının ne zaman kılınacağı ve nereye defnedileceği gibi bilgilere yer verilir. Eğer cenazenin yakınları gurbette ise telefon açılarak bilgilendirilir. Cenazenin yakınları cenaze törenine yetişebilecek durumda ise ölü defnedilmez, bekletilir. Aksi durumda -özellikle yurt dışında ise- hemen defin gerçekleştirilir. Genel anlamda ölünün bekletilmesi pek hoş karşılanmaz. Geçmişte Canik ilçesinin mahallelerinde ölüm haberi mahalle halkından iki gönüllü kişi ile diğer mahallelere ulaştırılırd1. Bu kişilere ölünün ruhu için çeşitli bahşişler verilirdi. Kişi eğer öğle saatlerinde ölmüş ve ikindi namazına yetiştirilemeyecek durumda olursa ertesi güne bekletilir. Ölümün duyurulması günümüzde medya araçları özellikle sosyal medya- kullanılarak yapılır. Ölen kişi tanınmış bir kişiyse çeşitli gazetelere ilan verilerek de duyuru işlemi yerine getirilmiş olur. Eğer ölen kişi genç ya da kalp krizi sonucu vefat etmiş ise uzaktaki akrabalarına alıştıra alıştıra söylenir. "Öldü" demek yerine "hastalandı" demek tercih edilir. Merkez ve diğer ilçelerde ölen kişinin ayakkabıları hem evde cenaze olduğunu duyurmak hem de ihtiyaç sahibi birinin alması için kapının önüne konulur. (K 6) 


\section{3. Ölünün Gömülmeye Hazırlanışı Ve Defin}

Ölüm gerçekleşince birtakım işlemler yapıldıktan sonra, kişiyi gömmek için gerek dinsel, gerek geleneksel bakımdan zorunlu olan diğer hazırlıklara geçilir. Örnek, bu hazırlıkları üçe ayırmaktadır: Yıkama, kefenleme ve cenaze namazı.$^{19}$ Her şeyden önce ölüyü defnetmek için acele edilir. Cenaze törenine katılmak için uzaktan gelecek kişiler varsa cenazenin bekletildiği de olur. Özellikle ikindiden sonra ölüm gerçekleşmişse bir sonraki günün öğle vaktine kadar bekletilir. Samsun yöresinde cenaze genellikle gece defnedilmez.

\subsubsection{Y1kama}

Diğer yörelerde olduğu gibi Samsun yöresinde de cenaze İslamî usullere göre yıkanır. Ölen kişi eğer erkekse erkek, kadınsa kadın yıkayıcı bu iş için görevlendirilir. Cenazeyi yakınlarının yıkadığı gibi bu işi meslek OMÜiFD edinmiş kişiler ya da gasilhane görevlileri tarafından yıkandığı da ifade edilebilir. Cenaze, yıkanmak üzere teneşir denilen yere ayakları kıbleye gelecek şekilde sırtüstü yatırılır. Göbek ile diz kapağı bir bezle kapatılmış olan cenazenin ağız ve burnuna bir parça pamuk tıkanır. Öncelikle cenazenin avret mahalli temizlenir. Yüzünden başlamak üzere abdest aldırılan cenazenin burun delikleri ve göbek çukuru mesh edilir. Daha sonra başı sabunla yıkanan cenaze önce sol tarafına çevrilerek sağ tarafı, sonra sağ tarafına çevrilerek sol tarafı yıkanır. Bu işlem üç kez tekrar edilerek cenazenin yıkanması tamamlanmış olur. Avret yerleri pamukla kaplanır. Havlu ile kurulanan cenazenin üzerine güzel kokular sürülür.

Alaçam ilçesinde ölünün yıkanacağ ölünün evinden alınmaz, komşulardan temin edilirdi. Ölü yıkarken gül suyu, sabun, susak, sır örtüsü, peşkir, lif gibi kullanılabilecek bir bez parçası da yıkama yerine alınırdı. Ölünün yıkanması bittikten sonra su artarsa ölünün üzerinden çıkanlar yıkanırdı. Yıkanan bu çamaşırlar ölünün

19 Örnek, Anadolu Folklorunda Ölüm, 48. 
kabre konulduğu ilk gece yakılırdı. Cenazenin yıkanması esnasında yakınlarına su döktürme geleneği de vardı. Ancak ölen kişi kadınsa artık kocasına mahrem sayıldı̆̆ı için yıkama yerine giremezdi. Cenazenin yıkanması sırasında ölünün yüzü yıkandıkça güzelleşirse o kişinin Cennet'e gideceğine dair yorumlar yapılırdı. Ayrıca ölü yıkanan yerde üç gece ya idare (gaz lambası) ya da çıra yakılır, ortam aydınlatılırdı. Günümüzde cenazenin yıkanma işlemi için belediyelerin araçları kullanılmaktadır. (K 20) Ayvacık ilçesinin mahallelerinde büyük kazanlarda su kaynatılıp etrafı kilim ya da halı örtülmüş yerde cenaze yıkanmaktadır. Ancak bazı mahallelerde yıkama işi için cenaze araçlarının kullanıldığı görülmektedir. (K 4) Asarcık ilçesinde ölünün yıkanması için hazırlanan suya el sokulmaz, bu nedenle suyun 1 lıklığı bir maşrapa yardımıyla kontrol edilir. (K 2) Atakum ilçesi Taflan yöresinde cenazenin yıkandığı yerde yıkama işi bittikten sonra tütsü yakılır. Çivril Mahallesi'nde geçmişte cenaze, evinin önünde yıkanırken günümüzde hastanede yıkanıp evine bu şekilde getirilmektedir. (K 13) Vezirköprü'nün Kületek Mahallesi'nde sadece cenaze yıkamada kullanılan "ölü yıkama lifi" bulunur. Bu lif başka OMÜIFD zamanlarda kullanılmaz. Yıkama işleminden sonra suyun içine "kâfur" adı verilen bir madde atılarak eritilir. Daha sonra bu su, ölümden sonra da ibadet edeceği düşüncesiyle ölünün secde yaparken yere değen yerlerine (alın, burun, diz kapağı, ayak ve ellerine) bir pamuk yardımıyla sürülür. Cenaze yıkama işlemi mahallelerde bu iş ayrılmış özel yerlerde yapılırken Vezirköprü şehir merkezinde belediyenin "Cenaze Yıkama Aracı" kullanılır. Teneşirin altında "buhur" yakılır. Ölüyü yıkayacak kişiler mutlaka abdestli olmak zorundadır. Mahallelerde ölü yıkayan kişilere para verilir. Vezirköprü'nün Nalbantlı Mahallesinde ölünün üzerinden çıkan elbiselere "soygun" adı verilir. Cesede ve kefene kokulu madde olarak bazen mis sürülür. (K 10) Kavak ilçesinde ölü yıkanırken yakınlarına su dökmek isteyip istemedikleri sorulur. İsteyen ölünün üzerine su döker. Ölünün yıkanmasından sonra artan suyu yakınları şifa niyetine el ve yüzlerine sürerler. Bu yörede kefenleme işlemi tamamlandıktan sonra sürülen maddenin adı "apron"dur. Cenazenin yıkanması mutlak surette dinî kurallara göre yapılır. Bazı yerlerde ölü kefenlendikten sonra yakın- 
ları, ölünün yüzünü açtırarak son kez görmek isterler. (K 18) Vezirköprü'nün Kületek Mahallesi'nde bir kişi ölünün yüzünü görüp eve gelirse ve evdekilerde yatıyorsa hemen kaldırılır. Aksi takdirde "ölü baskını" olacağına inanılır. Yine aynı yörede ölü baskınından evdekilerin etkilenmemesi için ölünün yüzünü gören kişi kimseye görünmeden tuvalete gider ve tuvaletini yapar. (K 10) Canik ilçesinde cenazenin yıkanması sırasında kullanılan sabun bir daha kullanılmaz. Ayrıca ölünün başına çörek otu serpilir, saçlarına kına yakılır. Ondokuz Mayıs ilçesinde cenazenin yıkanması sırasında tütsü yakılır. Salıpazarı Konakören Mahallesi'nde cenazenin yıkanması için kullanılan suyun tamamının bitirilmesine özen gösterilir. Bunun nedeni ise başka bir ölüm olayı olmaması içindir. Eğer ölen kişi yaşlı ise kefenlenmeden önce ölünün yakınları çağrılarak eli öptürülür. (K 5) Asarcık ilçesinde ölü yıkandıktan sonra artan su o gün cenazeden gelen biri tarafından basık olan çocukları yıkamak için kullanı-

252 lır. (K 2) Alevi kültür özelliklerinin görüldüğü Salıpazarı'nın Avut Mahallesi'nde cenazenin yıkanması için hazırlanan suyun adı "seyran suyu"dur. Bu su ile ölünün avret yerlerinin temizliği ile sakal tıraşı yapılır. ${ }^{20}$ Salıpazarı'nın bazı mahallelerinde ölünün yıkandığı yere su dolu bir sürahi ve bardak bırakılır. Bu uygulama ölünün ruhunun bu sudan içeceğine dair inanıştan kaynaklanmaktadır. Benzer bir uygulama Bafra ilçesinde de yapılmaktadır. Burada temel amaç ölünün ruhunun su içmesinin yanında abdest almasının da sağlanmasıdır. (K 19) Terme ilçesinde ölünün yıkanıp kefenlendikten sonra yüzünün açılması hoş karşılanmaz. Benzer bir durum Bafra ilçesi Sarpın Mahallesi'nde de olduğu için cenaze kefenlenmeden önce son defa yıkandığı yerde görülür. (K 19) Çarşamba ilçesinde ölüye abdest aldırıldıktan sonra sadece anne, baba, eş, çocuk, dayı, amca gibi yakınlarına gösterilir. Nikâh düşen kişiler cenazeyi göremez. (K 1) Salıpazarı ilçesinde hamile kadınlara ölünün yüzü gösterilmez. Çünkü doğacak çocuğun benzinin soluk olacağına inanılır. (K 5) İlkadım ilçesi Çivril Mahallesi'nde eskiden ölünün yıkandığı yerde kırk gece ışık yakılirdı. (K 17)

20 Ali Osman Aktaş, Avut Köyü'nün Halkbilimi Açısından Incelenmesi, (Samsun: Ondokuz Mayıs Üniversitesi, Sosyal Bilimler Enstitüsü, Yüksek Lisans Tezi, 2007), 95. 


\subsubsection{Kefenleme}

Kefen kelimesi sözlükte "ölüleri sarmak için kullanılan beyaz bez"21 olarak ifade edilmiştir. "Örtmek" manasına gelen Arapça "kefn" mastarından türetilmiştir. Hem ölünün saygınlığı hem de toplum sağlığı açısından son derece önemlidir. Diğer dinlerde olduğu gibi İslam dininde de cenazenin kefenlenmesine özel önem verilmiştir.

Samsun yöresinde cenazenin kefenlenmesi İslâmî usullere göre yerine getirilir. Yörede kefen olarak beyaz "hasse" kullanılır. Diğer pek çok yörede olduğu Samsun'da da "kefen parası"nın önceden hazırlaması geleneği devam etmektedir. Erkek kefeni üç, kadın kefeni beş parçadan oluşur: Bu parçalar erkek için gömlek, izar, lifafe; kadın için ise gömlek, izar, lifafe, baş ve gögüu örtüsüdür.

Kadın cenaze yıkandıktan sonra ilk önce temiz bir yere önce lifafe, sonra izar, daha sonra gömlek serilir. Son olarak da gögüs örtüsü yerleşti- 253 rilir. Tüm bunların üzerine koku veren maddeler -gülsuyu, OMÜíFD kâfur/kâfurun- sürülür. Cenaze bu bezlerin tam ortasına gelecek şekilde yerleştirilir. Önce göğüs, daha sonra gömlek cenazenin üzerine örtülür. Gömlekten sonra izar önce sol, sonra sağ olmak üzere kapatılır. Başörtüsü örtülür. Diğer parçalara göre daha büyük olan lifafe, aynı izar gibi önce sol, sonra sağ olacak şekilde kapatılır. Erkek cenazede ise göğüs ve başörtüsü olmadığı için kadın cenazesindeki uygulamanın benzeri yapılır. Son olarak hem kadın hem de erkek cenazenin kefeninin açılmaması için baş, bel ve ayak kısmı bir kuşakla bağlanır

Canik ilçesinde ölü mezara konulduğunda kefenin içine haşerat girmesin diye naftalin konulduğu da olur. (K 7) Salıpazarı ilçesinde kefen parasının yanında cenaze masrafları için kullanılmak üzere "ölüm parası" adı altında kenarda bir miktar para saklama âdeti günümüzde de uygulanmaktadır. (K 5) Bafra'da cenaze namazına kadar üç kez abdest kontrolü yapılır. Eğer abdesti bozulmuşsa yeniden abdest aldırılır. (K 14) Kavak ilçesinde cenaze kefenlenirken kefen aralarına gül suyu döküp karanfil

${ }^{21}$ Büyük Türkçe Sözlük, (Ankara: Türk Dil Kurumu, 1983), 640 
serpiştirilir. (K 18) Vezirköprü'nün bazı mahallelerinde kefenleme sırasında kadının alnına ve göğüs kısmına kâfur suyunda parmak ıslatılarak "La ilahe illallah" yazılır. Aynı yörede kefen parası önceden hazırlanmamışsa kefen alışverişini yakın akraba ya da komşulardan birisi yapar. Öldükten sonra ölünün kimsede hakkı kalmasın düşüncesiyle bu alışverişi yapan kişiye cenaze sahibi daha sonra parasını öder. (K 10) Geçmişte Samsun yöresinde insanlar kefenlerini hacdan getirirlerdi. Böyle bir uygulamanın yapılmasındaki amaç kabir azabının hafifleyeceği inancıdır. (K 6)

\subsubsection{Tabut}

Cenaze, kefenlenmesini takiben baş ve ayak ucundan bağlanarak tabuta konulur. Tabutun kapağının üzerine ölümle ilgili olan ayetlerin yazılı olduğu yeşil bir örtü örtülür. Bu örtünün üzerine de cinsiyet farklılığını belirtmek için çeşitli nesneler konulur. Bu nesne/nesneler erkekler için genellikle havlu, kadınlar için ise tülbenttir. Ölen kişi eğer genç bir kız ise tabutun üzerine gelinlik ya da kına elbisesi konulduğu da olur. Tutulan futbol takımının formasının da zaman zaman tabutun üzerine konulduğu da görülmektedir. Ölen kişi çocuk ise tabutun üzerine yine yeşil örtü konulur. Tabut küçük olduğu için bunun çocuk tabutu olduğu anlaşılır. Şehit cenazelerinde ise tabutun üzerinde sadece Türk bayrağı bulunur.

Cenaze tabuta konulduktan sonra helallik alınmak üzere evinin önüne getirilir. Ölünün yakınları ve komşulara genellikle masa ya da taburelerin üzerine konulmuş olan tabutun etrafında toplanırlar. Bir hoca tarafından yapılan dünyanın gelip geçici olduğu ve ahretle ilgili kısa bir konuşmadan sonra helallik alınır. Daha sonra cenaze namazının kılınacağ1 camiye götürülür. Diğer ilçe merkezlerinde kadınlar cenaze namazının kılınacağı camiye gitmezken son yıllarda merkez ilçelerde -özellikle İlkadım ve Atakum'da- kadınların da cenaze namazının kılınmasını izlemek için camiye geldikleri görülmektedir. Samsun'un merkez ilçelerinde tabut, cenaze arabası ile taşınırken diğer ilçelerde ve mahallelerde genellikle omuzlar üzerinde mezarlığa götürülür. 
Tabutun taşınması esnasında cemaat tarafından yorumlar yapıldı̆̆ı da bilinen bir gerçektir. Tabutu taşıyan kişiler için eğer tabut hafif gelmiş ise ölen kişinin günahının az olduğu ve Cennet'e gideceği, aksi durumda ise günahının çok olduğuna dair söylemler de bulunulur. Canik'te tabutun taşınması esnasında eğer tabut sallanırsa yakında aynı aileden yeni bir ölü çıkacağına dair inanış vardır. (K 6)

Alaçam ilçesinde kadın cenazelerinde tabutun baş kısmına üçgen şeklinde yapılmış "yaşmak" konulur. Kadın hiç evlenmemişse bu yaşmağın rengi beyaz olur. (K 20) Çarşamba'da tabutun üzerine ölen kişi kadınsa çember, erkekse ceket konulur. Yine aynı yörede tabutun taşınması sırasında tabut gıcırdarsa yakın zamanda aynı aileden başka birisinin daha öleceğine dair yorumlar yapılır. (K 1) Havza ilçesinde "Tabut çok ağır olur, sürekli gıcırdarsa; bu, yakın zamanda tekrar cenaze olacağına işarettir." 22 Birçok ilçede mezarlık yakınsa tabutu omuzlarda taşımanın sevap olduğuna dair inanış söz konusudur. Tabutu en az altı, en fazla sekiz kişi taşır. Canik ilçesinde ölümün peşine yeni bir ölüm olmaması için cenaze mezara indirildikten sonra tabut ters çevrilir. (K 6)

\subsubsection{Cenaze Namaz1}

Büyük Türkçe Sözlük'te "cenaze gömülmeden önce musalla taşının üstüne konulan tabutun önünde kılınan namaz"23 olarak tanımlanan cenaze namazı İslamiyet'e göre farz-ı kifâyedir. Cenaze namazı, ölünün yıkanması ve kefenlenmesinden sonra yerine getirilen dinî bir ritüeldir.

Samsun yöresinde cenaze namazı musalla taşının bulunduğu cami avlusunda kılınır. Mahallelerde mezarlıklarda da kılınmaktadır. Erkek cemaat tarafından kılınan cenaze namazına kadınlar katılmazlar. Zamanı müsait olan kişiler cenaze namazı kılmanın sevap olduğu bilinciyle namaza iştirak ederler. Cenaze namazına gelen kişiler caminin avlusunda sıralanmış olan ölünün yakınlarına başsağlığında bulunurlar. Musalla

22 Özdemir, Havza İlçesinin Genel Folklorik Yapısı, 196.

23 Büyük Türkçe Sözlük, 242. 
taşına konulan cenazenin hemen önünde imam, onun arkasında da cemaat saf tutar. Cenaze namazı iki rekât olarak ayakta kılınır.

Yörede cenaze namazı genellikle öğle ve ikindi namazının hemen ardından kılınır. Cenaze namazının sık olarak kılınmadığı yerleşim yerlerinde -özellikle mahallelerde- imam namazın kılınışını tarif eder. Er ya da hatun kişi niyetine denilerek namaza başlanır. Namaz bittikten sonra imam "Mevtayı nasıl bilirsiniz? diye üç kez sorar. Cemaat de "İyi biliriz." şeklinde cevap verir. Bu şekilde cevap verilmesinin temel nedeni ölünün arkasından kötü konuşmanın ya da yaptığı kötülüklerin dile getirilmesinin hoş karşılanmayacağı düşüncesidir. Daha sonra "Hakkınızı helal ettiniz mi?" diye üç kez de bu soruyu sorar. Cemaat "Helal olsun." der. Böylece cenaze namazı tamamlanmış olur. Namazın arkasından tabut ya omuzlarda ya da cenaze arabasıyla mezarlığa götürülmek üzere yola çıkarılır. Tabuta omuz vermenin sevap olduğu inancından hareketle cemaat birbiriyle yarış halinde olur. Bir süre tabutu taşıyan kişi yerini başka

OMÜIFD bir kişinin almasıyla birlikte arkadan gelen cemaate karışır.

\subsubsection{Defin}

Defnedilmek üzere mezarlığa götürülen cenaze, mezarın hemen yanına konulur. Kadın cemaat genel olarak mezarlığa gelmez. Ancak gelmişlerse defin işlemini uzaktan seyrederler. Mezar kazma işi mahallelerde cenaze yakınları ya da komşular tarafından yerine getirilirken Samsun merkezde bu işlem belediye görevlileri tarafından icra edilir. Mezarın derinliği kadınlar için göğüs, erkekler içinse göbek hizasıdır. Mezar derinliğinin fark11 olmasının nedeni Alaçam yöresinde "kadınların günahının çok olduğu" inancıyla ilişkilendirilmiştir. (K 20) Vezirköprü'nün Kületek Mahallesi'nde ölen kişinin mezarı kazılırken mezardan yılan çıkarsa ölünün günahının çok olduğuna ve mezarın onu kabul etmeyeceğine inanılır. Bu nedenle mezar başka bir yere kazılır. Diğer yörelerde olduğu gibi Samsun yöresinde de cenaze tabutsuz bir biçimde defnedilir. Cenazenin mezarl1ğa indirilmesi genellikle cenazenin yakınları tarafından yerine getirilmektedir. Ancak ölen kişi kadınsa kocası mahrem sayıldığı için mezara oğlu/oğulları tarafından indirilir. Mezara genellikle iki kişi iner. Biri baş 
diğeri de ayak kısmında bulunan kuşaklardan tutarak cenazeyi mezara yerleştirir. Cenaze sağ tarafına yatırılarak yönü kıbleye doğru döndürülür. Cenaze mezara yerleştirildikten sonra daha önceden hazırlanmış olan dokuz adet tahta çapraz bir şekilde dizilir. Cenaze törenine iştirak edenler sırayla mezara toprak atarlar. Mezara ilk toprağı ölünün en yakını olanlar atar. Mezara toprak atılırken küreğin elden ele verilmemesi ritüeli hemen hemen tüm yörede görülmektedir. Mezarın kapatılması oldukça hızlı bir şekilde olur. Son olarak mezarın baş ve ayak ucunu ölen kişinin adı soyadı, doğum ve ölüm tarihlerin yazılı olduğu tahta parçası sıkıştırılır. Bu tahtalar mezarın oturmasının beklendiği bir yıl boyunca orada kalır. Cenazenin defni sırasında Kuran okunur ve sonunda dua edilir. Mezar tamamen kapatıldıktan sonra bidon ya da kova ile mezarın üzerine su dökülür. Ayvacık ilçesinde bu suyun bir damlasının ölünün ağzına değdiğine ve böylece ölünün kafasını kaldırması sonucu başını tahtaya çarparak öldüğünü anladığına inanılır. (K 4) Çarşamba ilçesinde mezarın ayak ucunda durulursa ölünün o kişiyi göreceğine dair inanış vardır. (K 1) Mezarın baş ve ayak ucuna çam ve servi ağaçları dikilir. Mezarın üzeri ise susam ile süslenir. Mahallelerde kadınlar mezar ziyaretini definden bir gün sonra yaparlar. Samsun'un diğer yerleşim yerlerinden farklı olarak Ondokuz Mayıs İlçesi yörüklerinde arife günü yapılan ziyaretlerde mezarlığa şeker, buğday ve su götürülür. Şeker ziyarete gelen çocuklara verilir; su mezara dökülür, buğday da mezarın üzerine bırakılır. Bu uygulamadaki amaç kuşların ve böceklerin buğdayları yiyerek ölünün ruhuna sevap olması isteğidir. (K 3) Vezirköprü'de mezarın üzerine dökülecek suyu genellikle dilenmek için gelen fakir insanlar getirir. Cenaze sahipleri de definden hemen sonra bu kişilere para verirler. (K 10) Eskiden Lâdik, Çarşamba ve Asarcık ilçelerinde ölünün defnedildiği ilk gece ölü korkmasın diye bir fakire para verilir ve sabaha kadar mezar başında beklemesi istenirdi. Günümüzde böyle bir uygulamadan söz etmek mümkün değildir. Geçmişte var olan ancak günümüzde pek görülmeyen uygulamalardan biri de ölünün defnedildiği ilk gece mezar başında ateş yakma âdetidir. (K 12, 1, 2) Canik'te evde kırkı çıkmamış bebek varsa, mezardan dönen kişi bebeğin basık olmaması için önce ahıra ya da sa- 
manlığa girer. Böylece basık olmayacağı düşünülür. Evin içinde uyuyan kişi ya da kişiler varsa hemen kaldırılır. (K 6)

Cenaze, eğer sağlığında vasiyet ettiği bir yer varsa oraya gömülür. Mahallelerde cenazeler genellikle aile kabristanlığına defnedilirken Samsun merkezde Derecik Mezarlığı'na defnedilir.

Geçmişte cenaze merasimine katılanlar hep birlikte cenaze evine gelir ve orada yemek yerdi. Ancak günümüzde çalışma hayatı ya da farklı nedenlerle işine hemen dönmek isteyen kişiler için mezarlık çıkışında daha önceden hazırlatılmış olan pide ve ayran ikram edildiği görülmektedir. (K 1, 4, 6, 13)

Defin işlemi bittikten sonra hoca, ölüye talkın/talkun/telkin verir. Talkın, ölünün mezara konulduğu ilk akşam Münker ve Nekir meleklerinin ölüyü sorguya çekerken sordukları sorulara rahat cevap verebilmesi

258 için hatırlatma mahiyetinde bir uygulamadır. Bu uygulama cemaat daOMÜiFD ğıldıktan sonra yapıldığı gibi ölünün yakınları mezar başında olduğu durumlarda da yapılmaktadir.

Cenazenin defnedilmesinden sonra yapılan uygulamalardan biri de "1skat"tır. Iskat, ölünün hayatta iken kılamadığı namazları ve tutamadığı oruçları için verilen kefaret niteliğinde paradır. Her ne kadar din adamları bu konunun dinde yeri olmadığına dair ifadelerde bulunsa da toplum tarafından devam ettirildiği gözlemlenmektedir. Alaçam ilçesinde yaşayan mübadiller arasında iskat kavramı yerine "kefâret" kelimesi kullanılmaktadır. (K 20) Çarşamba ilçesinde ıskat muhtaç durumda olan kişilere verilmektedir. (K 1) Yukarı Avdan Mahallesi'nde 1skat, fakirlerin yanında cami, Kuran kursu gibi yerlere de verilir. (K 15)

\section{3. Ölüm Sonrası}

Samsun yöresinde ölüm öncesi ve sırasında yapılan pek çok uygulama ve ritüel olduğu gibi ölüm sonrasında da birçok ritüelin yerine getirildiğini söyleyebiliriz. Bu uygulama ve ritüeller genel anlamda Eski Türk kültürüne ait unsurlardır. 


\section{1. Ölü Evi}

Cenazenin defnedilmesinden sonra cenaze evinde yemek ikramı yapılır. Samsun yöresinde genellikle cenaze evinde yemek pişmez. Komşuların getirmiş olduğu yemekler cenazeye katılanlara ikram edilir. Son yıllarda Samsun şehir merkezinde belediyelerce organize edilmiş olan ekipler tarafından cenaze evinin önüne çadır kurulduğu, çay ikram edildiği, pide ve tatlı sunulduğu görülmektedir. Salıpazarı'nın mahallelerinde cenaze gömüldükten ikram edilen yemeğin adı "kazma kürek takırtısı"dır. (K 5) Ölünün ruhu için helva kavurma, geçmişten günümüze değişmeyen uygulamaların başında gelir. Cenazenin defnedilmesini takip eden özellikle ilk akşamdan başlamak üzere yedi gün boyunca ölü evinde dua edilir. Cenaze evi başsağlı̆̆ için gelenler nedeniyle uzun süre boş kalmaz. Cenaze evine taziye için gelenler "Başınız sağ olsun, Allah rahmet eylesin, Allah başka acı göstermesin, Allah sizlere uzun ömür versin." şeklinde taziyelerini sunarlar.

Çivril Mahallesi'nde ölen kişinin evinde yedi gün ışık yakılır. Evin içinde kelebek görülürse ölünün ruhunun evde dolaşttğına inanılır. Ölen kişinin mezarında azap çekeceği düşüncesiyle cenaze evinde yüksek sesle ağlamak hoş karşılanmaz. Vezirköprü'nün Oymaağaç Mahallesi'nde cenaze evinde eğer arı görülürse ölen kişinin ruhunun geldiğine inanılır ve ölü kendisi için Kuran okunmasını istiyor, şeklinde yorumlar yapılır. Salıpazarı Konakören Mahallesi'nde ölünün evden çıktığı gün cenaze evinde yağ kokutulur. Samsun yöresinde taziyeye gelen misafirler giderken uğurlanmaz, güle güle denilmez. (K 5)

\subsection{Belirli Günler}

Eski Türklerde ölen kişi için yapılan anma törenlerinin gömülme veya ölüm gününden sonraki üçüncü, yedinci ve kırkıncı günü ile yıl sonunda yapıldığı düşünülmektedir. ${ }^{24}$ Anma törenlerinin işlevsel yönü ise insanlara yaşanan kayıptan ötürü duygularını ifade etme olanağı vermek ve duyguların biçimsel, resmî biçimde dışarı vurulmasına aracı olmaktır.

24 Jean Paul Roux,Türklerin ve Moğolların Eski Dini, (İstanbul: Kabalcı Yayınları, 2002), 225. 
Birçok insan sevdiklerinin anısını yâd edeceklerine ve kendilerini rahatlatacaklarına olan inançla bu törenlere sahip çıkmaktadırlar. ${ }^{25}$

Cenazenin defnedilmesini takip eden yedisi, kırkı, elli ikisi ve sene-i devriyesi ölünün özel günleri olarak kabul edilmektedir. Bu özel günlerde birtakım uygulama ve pratiklerin yapıldığı bilinmektedir.

Ölünün mezara konulmasından sonraki yedinci gün mevlit okutulur. Mevlitten sonra gelen misafirlere yemek ikramında bulunulur. Bu yemek mahallelerde genellikle sulu olurken şehir merkezinde ise pide, etli pilav, tatlı ve ayrandan müteşekkildir. Mevlit genellikle hocalar tarafından okunmaktadır. Mevlitten sonra hocalara zarf içerisinde bir miktar para verilir. Mevlit okunurken kadın ve erkekler ayrı odalarda olurlar. Ölünün kırkıncı gününde yine yedisine benzer bir uygulama yapılır, elli ikinci günde ise etinin kemikten ayrıldığına dair inanış söz konusu olduğu için yine ölünün ruhuna Kuran okutulur ve çeşitli ikramlarda bulunulur. Ölümün üzerinden bir yıl geçmesi yörede sene-i devriye olarak adlandır1lir ve yine hayır hasenat yapılır.

Canik ilçesinde bayram geceleri helva kavrulur. Ölünün ruhunun kokusunu duyması için yanan ateşe yağ ve un atılır. Yayla Mahallesinde bu uygulama hala sürdürülmektedir. Cuma ve bayram geceleri helva kavrulurken ölünün ruhunun haberdar olması için aktardan satın alınan "buhara kabuğu" tüttürülür. ${ }^{26}$ Alaçam ilçesinde yedi gün boyunca tevhit çekilir ve ölünün ruhuna armağan edilir. Yine aynı yörede ölünün kırkıncı gününe kadar hatim indirilir ve kırkıncı akşam hatim duası yapılır. Ölünün ruhunun cuma ve pazartesi geceleri evini ziyaret edeceği inancından hareketle evde güzel koku olsun diye küle tereyağı atma geleneği vardı. Ancak bu uygulama günümüzde yalnızca bazı mahallelerde sürdürülmektedir. (K 20)

25 Constance Jones, Huzur İçinde Yatsın - Ölüme Dair Her Şey, çev., Mehmet Gürsel, (İstanbul: Dharma Yayınları, 2004), 370.

26 Sönmez, Samsun İli Canik İlçesi Geçiş Dönemi Âdetlerinde Görülen Kültürel Değişimler, 89. 


\section{3. Ölü Aşı/Yemeği}

Ölünün ardından ölü aşı verme geleneği çok eskilerden beri Türk kültüründe var olan bir uygulamadır. Kabirde yatan ölünün rahat etmesi amacıyla yapılan bu uygulama, aynı zamanda ölüyü anmak anlamını da taşır.

Samsun yöresinde "cenaze sonrasında helva ekmek dağıtılır ve buna canlık denir. Canlık ölünün ruhuna şefaatçi olur."27 Alaçam ilçesinde cenaze evine gelenler kesinlikle aç gönderilmez, mutlaka ikramlarda bulunulur. Eğer aç giderse ölünün ruhunun acı çekeceğine inanılır. (K 20) Salıpazarı ilçesinde ölü evinde üç gün yemek pişirilmez. Çünkü ölüm esnasında etrafa kan sıçradığına dair inanış söz konusudur. (K 5) Ayvacık'ta ölümden sonraki ilk Cuma gecesi ölünün yakınları tarafından $\mathrm{Ku}$ ran okutulup gelen herkese yemek yedirilir. (K 4) Vezirköprü'de cenazeye katılanlara o gün içinde olmak koşuluyla cenaze evinde, ev müsait değilse komşu evinde yemek yedirilir. (K 10) Yukarı Avdan Mahallesi'nde ölünün yedisi için Kuran okunurken gelenlere şerbet ikram edilir. Günümüzde Çivril Mahallesi'nde yemek vermek yerine kıymalı pide ikramı yapılmaktadır. (K 15) Bafra'da ölünün defnedilmesinden itibaren kırk gün boyunca cenaze evinde Yasin okutulur ve kırkıncı gün yemek verilir. (K 14) Taflan'da ölünün ruhu için okutulan mevlitten sonra kek ve meyve suyu ikram edilir. (K 13) Çarşamba ilçesinde ölünün defnedilmesinden sonra yemek yerine daha kolay hazırlanabilecek ikramlarda bulunulur: Kıymalı pide, ayran, helva ekmek gibi. (K 1) Avut Mahallesi'nde "mevtanın toprağa girdiği akşam Kabir Kurbanı kesilir ve lokma edilerek cemaate dağıtılır."28

\section{4. Ölünün Eşyaları}

Samsun yöresinde ölünün kıyafetleri genel olarak fakirlere dağıtılır. Ancak cenazenin yakınları kendileri için manevi değeri olan eşyaları vermez, hatıra için saklarlar. Kıyafetlerden çok eski olanlar yakılarak imha edilir. Ölünün eşyalarından ilk olarak ayakkabıları kapının önüne konu-

\footnotetext{
Şişman, Samsun Yöresinde Yaşayan Halk İnançları Üzerine Bir İnceleme, 75.

Aktaş, Avut Köyü'nün Halkbilimi Açısından İncelenmesi, 97.
} 
lur. Bu uygulama hem evde ölü olduğunu etrafa duyurmak hem ihtiyacı olan bir fakirin almasını sağlamak hem de ölümü evden uzaklaştırmak düşüncesiyle yapılmaktadır. Bazen ölen kişinin elbiselerinden hiçbirinin verilmediği, elbise dolabının hiç bozulmadığı ve aynen korunduğu da görülmektedir. Bunun altında yatan temel neden ise ölümü kabullenememedir. Bafra'da ölen kişi kadınsa, kıyafetleri mahallede oturan dul bir kadına verilir. Canik ilçesi Kızıloğlak mahallesinde ölünün eşyaları yakılmaz. Ya fakirlere ya da hayır kurumlarına verilir. (K 6) Lâdik ilçesinde geçmişte ölünün eşyalarının verileceği kişinin namazlı abdestli, dini bütün bir kişi olmasına dikkat edilirdi. (K 12)

\subsection{Yas Tutma}

Ölünün ardından yakınları belirli bir süre birtakım davranışları yapmaktan kaçınırlar. Türk kültüründe yas, geçmişi çok eskilere dayanan bir uygulamadır. Divan-ü Lügat-it Türk ve Dede Korkut Hikâyelerinde yas ile ilgili pek çok uygulamanın yer aldığı söylenebilir. Bamsı Beyrek Hikâyesinde Beyrek'in ölümü üzerine şu ifadelere yer verilir: "Beyregün babası kaba saruk götürüp yire çaldı, tartdı yakasın yırtdı, oğul oğul diyüben bögürdi, zarılık kıldı. Ağ pürçeklü anası buldur buldur ağladı gözinün yaşın dökdi, acı tırnak ağ yüzine aldı çaldı, al yanağın tartdı, kargu gibi kara saçını yoldı, ağlayuban ısıklayubanı ivine geldi. Pay Püre Bigün dünlügi altun ban ivine şiven girdi. Kızı gelini kas kas gülmez oldı, kızıl kına ağ eline yakmaz oldı. Yidi kız kardaşı ağ çıkardılar kara tonlar geydiler"29 Tarihsel anlamda Türk kültüründe yasın temsilî rengi siyahtır.

Samsun yöresinde yas tutmanın süresi ölen kişinin genç ya da yaşlı olması ile doğrudan ilişkilidir. Yaşlı ölümlerinde yasın süresi bir hafta ile on gün arasında değişirken genç ölümlerinde bu sürenin çok daha uzun olduğu gözlemlenmektedir. Yas süresince süslü ve renkli kıyafetler giymekten mümkün olduğunca kaçınılır. Yasta olan kişiler düğünlere gitmez, radyo dinlemez ve televizyon izlemezler. Salıpazarı ilçesinin bazı mahallelerinde mevcut durumun tersine dönmesi yani tekrar ölüm ol- 
maması için yas süresince elbiseler ters giyilmektedir. (K 5) Lâdik ilçesinde cenazenin defninden sonraki yedi sekiz gün içinde yemek pişirilmez, komşular yemek getirir. Ayrıca cenaze yakınları yas süresince hamama gitmezler. (K 12) Vezirköprü'de yas süresi 3-5 gün arasındadır. Sevinilecek bir durum olsa dahi aşırılıktan kaçınılır. (K 10) Çarşamba'da geçmişte yas süresi daha uzun tutulmaktaydı. Günümüzde ortalama üç ila beş gün arasında değişmektedir. Ancak bazı ailelerin yas süresinin bir yıldan da fazla sürdüğü ifade edilebilir. Ayrıca ölünün defnedildikten sonraki ilk günlerinde yaptığı iyiliklerden bahsedilir. (K 1) Asarcık'ta yas süresince cenazenin ardından çok ağlanırsa ölünün su içinde kalacağı ve ruhunun o kişinin rüyasına gireceğine dair inanış vardır. (K 2) Geçmişte Ayvacık'ta ölen kişinin komşularının düğünü varsa ya düğün ertelenir ya da yakınlarından izin alınarak süresi oldukça kısa sade bir düğün yapılırdı. Ölünün yakınları yapılan düğünlere katılmazdı. Ancak günümüzde bu âdete insanların pek uydukları söylenemez. (K 4) Yukarı Avdan Mahallesi'nde kadınların erkeklere oranla daha uzun süre yas tuttukları söylenebilir. (K 16) Canik ilçesinde ölünün yakınları şehir dışından gelmişler ve yas süresini üç günden önce bitirip ölü evinden ayrılmışlarsa bu durum ayıplanır, hoş karşılanmaz. Ölüye yeterince saygı göstermedikleri ve vefasız oldukları kendilerine hissettirilir. (K 6)

\subsection{Başsağlığı/Taziye}

Samsun yöresinde taziye geleneği oldukça yaygındır. Taziye, ilk olarak cenaze namazından önce camide başlar. Ölünün yakınları musalla taşının hemen yanında sıralı bir şekilde dizilir. Burada başsağlığı dileğinde bulunulur. Yatıştırıcı sözlerle cenaze yakınları teskin edilmeye çalışılır. İkinci taziye mezarlığın çıkışında gerçekleşir. Camideki uygulamanın bir benzeri burada da yapılır. Genellikle kadınlar cami ve mezarlığa gelmedikleri için taziyeleri evde kabul ederler.

Geçmişte olmayan ancak günümüzde sıklıkla karşılaştığımız bir uygulama belediyelerin cenaze evinin önüne taziye çadırı kurmalarıdır. Bu taziye çadırlarının içinde plastik sandalyeler ve çay kazanları bulunur. Taziyeye gelen erkekler eğer ev müsait değilse burada karşılanır ve taziye 
burada verilir. Taziyede söylenen sözler hemen hemen diğer yörelerle aynıdır: "Allah rahmet eylesin, başınız sağ olsun, Allah sabırlar versin, mekânı Cennet olsun, Allah başka acı göstermesin, Allah sizlere hayırlı, uzun ömürler versin, son acınız olsun." vb.

Taziyeye gelen kişilere ölünün ruhu için yemek verilir. Genellikle pide ve ayran ikram edilir. Sunum ise komşular tarafından gerçekleştirilir. Taziyenin süresi uzun olmaz. Taziyede amaç cenaze sahiplerinin ac1sını hafifletmek, onların yanında olduklarını göstermek ve bir an önce normal yaşantılarına dönemlerini sağlamaktır.

\subsection{Mezarlıklar Ve Mezar Taşları}

Samsun şehir merkezinde Şehir, Kıranköy ve Derecik Mezarlı̆̆1 olmak üzere üç mezarlık vardır. Şehir Mezarlığı ve Kıranköy'e daha önceden mezar yeri almış olanlar defnedilirken mezar yeri satın almamış olanlar

264 ise Derecik Mezarlığı'na sıralı olarak defnedilirler. Mahallelerde ise me-

OMÜiFD zarlıklar mahallenin uzak ve yüksek yerlerinde bulunur. Şehir merkezindeki mezarlıklar, belediyenin düzenli ilgilenmesi sayesinde daha bakımlı ve düzenli iken mahalle mezarlıkları genelde bakımsızdır. Şehir mezarlıklarının belli giriş çıkış kapıları vardır. Mahallelerdeki mezarlıkların birçoğu tahta kazıklara tutturulmuş tel örgüler ile çevrilidir. Samsun şehir merkezinde yer alan Şehir Mezarlığı ile Kıranköy Mezarlığı'nda aile kabristanlıklarının sayısı bir hayli fazladır.

Diğer yörelerde olduğu gibi Samsun yöresinde de yeni ölmüş birinin mezarı hemen yaptırılmaz. Mezarın oturması için defnin üzerinden yaklaşık bir yıl geçmesi beklenir. Daha sonra genellikle mermerden mezar yaptırılır. Az da olsa ölmeden önce mezar yerini yaptıranlar da vardır. Mezar şekilleri ve kullanılan malzemeler ailenin ekonomik durumuna göre farklılık gösterebilir. Mezarın baş tarafına sütun mezar taşı dikilir. Mezar taşlarında genellikle ölen kişinin adı, soyadı, doğum ve ölüm tarihleri ile Ruhuna Fatiha yazılır. Bazı mezar taşlarında şiirsel ifadelerin yer aldığı da bilinmektedir. Bunların yanında ölen kişinin mesleği, nasıl öldüğü ile ilgili bilgiler de yer alabilir. Dünyanın gelip geçici olduğuna 
dair sözler de ölünün ağzından mezar taşlarına yazılmaktadır: "Ey benim kabrimi ziyaret edenler, benden ibret aldınız mı? Dün sizin gibi idim, yarın benim gibi olacaksınız." Yörede bazı mezar taşlarında maniler de mevcuttur: "Kebabı köz öldürür / Ateşi su söndürür / Yiğidi kılıç kesmez / Bir acı söz öldürür."

Mezarın ayak ucuna ise kuşların su içmesi için oyuk oluşturulur. Buradan su içen kuşlar sayesinde ölünün mezarında rahat edeceğine inanılır. Mezarın üstüne basmak hoş karşılanmaz. Eğer basarak geçmek zorunda kalınırsa mutlaka besmele çekmek gerekir.

"Eski Türklerde mezarın yanında ağaç bulunması gerekiyordu. Zira ağaç ölüm ve yeniden doğuşun simgesiydi. Cengiz Han da mezar yeri olarak bir ağacın altını seçmiştir."30 "Mezarların süslenmesinde ağaç olarak genellikle servi, akasya, asma, çam, iğde, kavak; çiçek olarak gül, zambak, karanfil, menekşe ve sümbül; ot olarak da pelin ve arapsaçı gibi otlar kullanılmaktadır."31 Samsun yöresinde mezarlıklarda genel olarak çam ağacı bulunur. Mezarın üzerinin süslenmesi ise ağırlıklı olarak susam bitkisi ile yapılır. Canik'te mezarlıkta bulunan meyve ağaçlarının meyvesi kesinlikle yenmez; ağaca ölünün etinin karıştığı inancı vardır. Ayrıca mezarlıkta çiçek koparmak ve hayvan otlatmak da günah sayılır. (K 6) Samsun ve ilçelerinde mezar taşlarını okumanın ve parmakla göstermenin unutkanlığa sebep olacağı düşünülür. Mezarlıklarda bulunan yeşilliklerin canlı oldukları ve ölünün ruhu için zikir yaptıklarına dair inanışlar olduğu için bunların koparılmaması gerekir. (K 1, 7, 8, 12, 18)

Ayvacık ilçesinde mezardaki toprak yığıntısı kısa sürede çöken insanın günahının çok olduğuna inanılır. (K 4) Canik ilçesinde ise mezar üzerindeki toprak çökmüşse "ölüyü toprak kabul etmedi" diye düşünülür. (K 7)

\footnotetext{
Roux, Türklerin ve Moğolların Eski Dini, 215.

31 Sedat Veyis Örnek,.Türk Halk Bilimi, (Ankara: Bilgesu Yayınları, 2014), 324.
} 


\subsection{Mezar Ziyaretleri}

Türk toplumunda geçmişten günümüze mezar ziyaretlerine son derece önem verilmiştir. Mezar/lık/1 ziyaret etmenin çok sevap olduğu inancından hareketle belli zamanlarda ziyaretler gerçekleştirilir.

Samsun yöresinde definden sonra ilk ziyaret hemen ertesi gün yapilır. Bundan sonra cuma günleri ziyaret edilir. Bu durum cuma gününün Müslümanlar için kutsal oluşuyla alakalıdır. Ayrıca her bayram öncesi arife gününde mutlaka mezar ziyareti yapılır. Mezarlığa abdestli gitmeye özen gösterilir. Mezarlığa girince ilk önce selam verilir ve mezarlık temizlenir. Ölünün ruhu için Kuran okunur ve dua edilir. Yukarı Avdan Mahallesi'nde gece mezar ziyareti yapılmaz. Gece ölülerin ruhlarının dolaştığına inanılır. İkindiden sonra da mezar ziyareti yapılmaz inanışı hâkimdir. (K 16)

\section{4. Yeni Tip Koronavirüs (Kovid-19) Sonrası Değişen Ölüm Âdet Ve}

OMÜIFD Uygulamaları

İlk olarak 2019 yılı sonunda Çin'in Wuhan şehrinde görülen ve buradan da hemen hemen dünyanın her tarafına yayılan Yeni Tip Koronavirüs (Kovid-19), tüm insanlığ1 tehdit eder konuma gelen çok ciddi bir salgın hastalık konumundadır. Dünya Sağlık Örgütü (DSÖ) tarafından pandemi (küresel salgın) ilan edilmesi tehdidin boyutlarını gözler önüne sermesi bakımından dikkate değerdir. Bu küresel salgının bertaraf edilmesi noktasında ulusların ortak çalışmalar yaptığı ve pek çok konuda birlikte hareket ettikleri görülmektedir.

Yeni Tip Koronavirüs'ün Türkiye'de ilk kez görüldüğü 11 Mart 2020 tarihinden itibaren Sağlık Bakanlığı Koronavirüs Bilim Kurulu, salgının önlenmesi noktasında önemli tavsiye kararları almış ve almaya da devam etmektedir. Bahse konu tarihten sonra Sağlık Bakanlığınca günlük olarak koronavirüsle ilgili istatistikî sayıları içeren vaka tabloları kamuoyuyla paylaşılmıştır. 23 Mart 2021 tarihi itibariyle Türkiye'de toplam vaka 
sayısı 3.061.520, toplam vefat sayısı ise 30.316'ya ulaşmıştır. ${ }^{32}$ Dünya Sağlık Örgütü'nün 23 Mart 2021 tarihli raporunda dünya genelinde toplam vaka sayısı 123.419.065, vefat sayısı ise 2.719.163 olarak açıklanmıştır. ${ }^{33}$ Açıklanan bu sayılar salgının dünya toplumları için son derece ciddi bir salgın hastalıkla karşı karşıya kalındığının bir göstergesi olarak değerlendirilebilir.

Yeni Tip Koronavirüs (Kovid-19); eğitim, sağlık, teknoloji, ekonomi başta olmak üzere pek çok alanı etki altına almasının yanında toplumların sosyal ve kültürel hayatlarını da derinden etkilemiştir. Halk kültürü ile ilgili doğrudan ilişkili olan birçok uygulama ve pratiklerin bu süreçte ya uygulanmadığ 1 ya da kısmen yerine getirildiği söylenebilir.

Geçiş dönemi âdet ve uygulamaları içerisinde değişimden belki de en az etkilenenlerden biri de ölümle ilgili olanlarıdır. Ancak son aylarda Yeni Tip Koronavirüs'ten ölen kişilerin yıkanması, kefenlemesi, cenaze namazı, defni gibi pek çok uygulamada önemli değişiklikler yaşandığını belirtmekte yarar vardır. Diyanet İşleri Başkanlığına bağlı Din İşleri Yüksek Kurulu, salgın hastalık riskinin bulunduğu durumlarda cenazenin nasıl yıkanacağı nasıl yapılacağına dair önemli kararlar almıştır:

"Salgın hastalık riskinin bulunduğu durumlarda cenaze namazının, olabildiğince az sayıda kişiyle ve bekletmeden kılınması tercih edilmelidir. Ayrıca hastalığın bulaşmaması için gerekli tedbirler alınmalı, bu bağlamda cenaze namazına iştirak edenler arasında yeterince mesafe bırakılmalıdır. Bu durumda birden fazla cenaze varsa hepsi için tek bir namaz kılınması yeterlidir. Hastalığı bulaştırma riski sebebiyle yetkililerce hemen defnedilmiş olan cenazenin namazı daha sonra kabrine karşı birkaç kişiyle kılınabilir.

32 Sağlık Bakanlığı, “Covid-19 Bilgilendirme Sayfası”, (Erişim 23 Mart 2021).

33 World Health Organization, Coronavirus disease (COVID-19) Weekly Epidemiological Update and Weekly Operational Update, (Erişim 23 Mart 2021). 
Hastalığın bulaşma riskine karşı uzmanların tavsiyeleri doğrultusunda gerekli koruyucu tedbirler alındıktan sonra cenazenin usulüne uygun bir şekilde yıkanıp kefenlenmesi ve defnedilmesi gerekir. Alınacak bütün bu tedbirlere rağmen cenaze yıkandığı ve usulünce kefenlendiği takdirde bu hastalığın başkalarına da sirayet etme tehlikesi varsa:

1. Uzaktan cenaze üzerine su tutularak veya serpilerek yıkama işlemi gerçekleştirilir.

2. Bu uygulamanın da riskli olduğu durumlarda yetkililerin de talimatlarına uyularak koruyucu kıyafetlerle cenazeye teyemmüm aldırılır.

3. Cenazeye teyemmüm yaptırılmasının da hastalığın bulaşması açısından riskli olduğu hallerde zaruret sebebiyle teyemmüm de terkedilir ve o haliyle namazı kılınarak defni sağlanır.

Cenazelerin, geleneksel yöntemle açılan kabre kefenle defnedilmesinin de riskli olduğu durumlarda, ceset torbası veya tabutla defnedilmesi de caizdir."34

Yeni Tip Koronavirüs sonrası dikkati çeken önemli hususlardan biri de, ölünün selâsını verme zamanında görülen değişimdir. Samsun'da genellikle sabah 8'den sonra duyulan cenaze selaları virüsün yayılmasıyla birlikte günün her saatinde verilir olmuştur. Ayrıca virüs nedeni ile vefat eden kişilerin hemen defnedilmesi gereğince cenazenin evde bekletilmesi geleneği de terk edilmiştir. (K 21)

Türkiye'nin diğer yörelerinde olduğu gibi Samsun'da da yukarıda belirtildiği üzere Din İşleri Yüksek Kurulunun kararları çerçevesinde hareket edilmektedir. Gasilhaneye getirilen cenazenin yıkanması dinî vecibelere uygun bir şekilde yerine getirilmektedir. Cenazenin yıkanmasına başlanmadan önce gassalların nitril pudralı eldiven, maske, siperlik, özel gözlük taktıkları ve tulum giydikleri görülmüştür. Kovid-19'un yayılmasından önce cenazenin yakınlarının yıkama alanına alınması ve cenazeye su dökmesi gibi uygulamalara virüsün bulaşma riskinden dolayı izin 
verilmemeye başlanmıştır. Kovid-19'dan ölenlerin cenazesinin yıkama işlemi tamamlandiktan sonra, cenaze önce temiz bir havluyla daha sonra naylonla çepeçevre sarılmaktadır. Ardından iki kat kefenle kefenlenmektedir. Koronavirüs'ten ölenler, virüsün Türkiye'de ilk görüldüğü zamanlarda ceset torbası ile gömülmekteydi. Ancak bu uygulamaya son verildiğini belirtmekte yarar vardır. (K 21) Ölünün cenaze arabasına konulması da Samsun Büyükşehir Belediyesi'nin görevlendirdiği görevlilerce gerçekleştirilmektedir. Eğer cenaze yakını tabuta omuz vermek isterse maske ve eldiven takması için görevlilerce uyarılmaktadır.

Cenazenin yıkanmasından sonra helallik alınmak üzere evinin önüne getirilmesi uygulaması yerine doğrudan mezarlığa götürülmesi ve defnedilmesi uygulaması yaygınlaşmıştır. Bu durum cenaze namazının kılınma zamanında da değişimi beraberinde getirmiştir. Kovid-19 öncesinde Samsun'da cenaze namazları genellikle öğle ve ikindi namazlarına müteakip kılınmaktaydı. Son zamanlarda virüsün bulaşma riskini en aza indirmek gayesiyle belirtilen vakitlerin dışında da cenaze namazlarının kılındığ1 görülmektedir. Kovid-19'dan ölenlerin cenaze namazlarının mezarlıkta sınırlı sayıda cemaatle -cenaze yakınları ve görevliler- kılındığ1 ifade edilebilir. Mezarlıkta kılınan cenaze namazlarında da imam, sosyal mesafenin korunması noktasında gerekli uyarıları yapmaktadır.

Diğer yörelerde olduğu gibi Samsun yöresinde de cenazeler kefenle defnedilmektedir. Kovid-19'un yaygın bir şekilde görüldüğü büyükşehirlerde -özellikle İstanbul- tabutla gömülen cenazeler olmasına karşın Samsun yöresinde cenazelerin kefenle gömüldüğünü belirtebiliriz. Kovid-19'un Türkiye'de görülmeye başladığı ilk zamanlarda Samsun yöresinde virüs nedeniyle ölenlerin cenazelerinin gece defnedildiği de olmuştur. (K 21) Tabuttan çıkarılan cenaze baş ve ayak kısımlarından geçirilen urgan ya da kuşaklar yardımıyla mezara yerleştirilmektedir. Cenazenin mezara indirilmesi işlemi cenaze yakınlarınca değil tulum giymiş özel görevliler tarafından yerine getirilmektedir. Ölünün mezara yerleştirildikten sonra üzerine toprak atılması işlemi de yine görevlilerce yapılmaktadır. Cenaze yakını mezara toprak atmak isterse görevliler tarafından verilen eldiven 
ve maskeyi takarak bu uygulamayı yerine getirebilmektedir. Kovid-19 öncesinde cenazenin defni sirasında okunan Yasin, Tebareke, Amme, İhlâs, Felâk, Nâs, Fatiha gibi sûreler Kovid-19 sonrasında -insanların bir arada bulunma sürelerinin kısaltılması amaciyla- sadece Yasin sûresi ile sınırlandırılmıştır. İmamın ölüye talkın verme uygulamasında herhangi bir değişim söz konusu değildir.

Cenazenin defni sonrasında taziye sunma şeklinde de bir değişim söz konusudur. Cenaze defnedildikten sonra ölen kişinin yakınları mezarl1ğın çıkışına yakın bir yerde sıra ile dururlar. Cenazeye katılanlarca virüsün bulaşma riskinden ötürü tokalaşma ve musafaha (sarılma) olmaksızın ve maske takmış biçimde sağ elini kalp hizasına getirerek selamlaşma ve taziyede bulunma geleneği oluşmuştur.

Yaklaşık son on yıldır Samsun'da belediyelerce organize edilen cenaze evinin önüne taziye çadırı kurma, çay ikramı yapma, kıymalı pide gönderme gibi uygulamaların virüsün bulaşma riskinden ötürü uygulanmadığını belirtmekte yarar vardır.

Ölünün belirli günlerde anılması ve ruhuna dua edilmesi amacıyla yapılan anma günlerinde de kısmen değişim görülmektedir. Bu anma günleri aile içerisinde sınırlı kalmak kaydıyla az kişiyle yerine getirilmektedir. Taziye için cenaze evine giden kişilerin tokalaşma, musafaha gibi uygulamaların da bu dönem için kalktığını söyleyebiliriz. Ölünün arkasından camilerde mevlit okutma uygulamasına da bu salgin döneminde hemen hemen hiç rastlanmamıştır.

\section{Sonuç}

Ölümle ilgili inanç ve uygulamalara bakıldığında pek çoğunun ölen kişinin öbür dünyaya en iyi bir şekilde yolcu edilmesini sağlamak olduğunu rahatlıkla söyleyebiliriz. Ayrıca bu uygulama ve ritüellerin bir kısmı da geride kalan ölü yakınlarının psikolojik olarak rahatlatılmasına yöneliktir. Toplumsal sağlığın korunması ve hayatın olağan akışında sürdürülmesi toplumda yaşayan pek çok bireyin arzusu olduğunu da ifade etmekte yarar vardır. Toplumsal birlikteliğin sağlanmasına da önemli katkıları 
olan bu uygulamalar bireyin sosyal bir varlık olduğunun da önemli bir göstergesi olarak değerlendirilebilir.

Samsun yöresindeki ölüm âdetlerinin çok az değişiklikle geçmişten günümüze kadar geldiği söylenebilir. Ölüm ve ötesiyle ilgili inanış ve ritüellerin bir kısmının İslamî kaynaklı olması, bir kısmının da eski Türk inançlarından izler taşıması nedeniyle diğer geçiş dönemlerine göre değişimden daha az etkilendiğini ifade edebiliriz. Ölümle ilgili olarak ölümü düşündüren ön belirtiler, ölün anı, ölümün duyurulması, cenazenin yıkanması, kefenlenmesi, namazı, defni günümüzde de devam eden uygulamalardır. Ölüm ve ötesi ile ilgili bilgilere ilahî dinlerin verdiği bilgiler ışığında erişilebilmekte; bu nedenle de ölüm konusuna oldukça fazla önem verilmektedir. Ölüm ile ilgili uygulama ve ritüellerin şehir merkezlerine nazaran kırsal kesimlerde daha canlı bir biçimde yaşatıldı̆̆ını söylemek de mümkündür.

Samsun'da ölüm âdetlerinin bir kısmında son yıllarda birtakım değişimler yaşandığını belirtmekte yarar vardır. Geçmişte cenazeler evin önünde ya da caminin bu iş için ayrılmış bölümünde yıkanırdı. Ancak teknolojik gelişmelere paralel olarak modern cenaze yıkama araçlarının ya da hastanelerin gasilhanelerinin kullanıldığını söyleyebiliriz. Cenazenin defnedilmesinden sonra pratik olması bakımından pide ve ayran (bazı cenaze törenlerinde meyve suyu ve kek) ikramının tercih edildiği gözlenmektedir. Değişimin yaşandı̆̆ı uygulamalardan biri de kadınların hem cenaze namazı için camiye hem de cenazenin defnedilmesini izlemek için mezarlığa gelmeleridir. Iskat uygulamasının din görevlilerinin bu konu üzerine yapmış oldukları ısrarlı çalışmalar neticesinde geçmişe nazaran azaldığı söylenebilir. Ölümün duyurulması konusunda sela verdirmenin yanında sosyal medyadan da yararlanılması değişimin yönünü göstermesi bakımından dikkate değerdir.

Samsun yöresinde değişmeyen unsurların başında cenazenin defin zamanı gelmektedir. Cenaze mutlak surette ya öğle ya da ikindi namazını müteakip kılınan cenaze namazından sonra defnedilmektedir. Yaz aylarında bazen ikindi namazı sonrasına bırakılabilen cenaze defin törenleri 
kış aylarında günün kısalığı nedeniyle genel olarak öğle namazı sonrası icra edilmektedir. Ayrıca defin sırasında küreğin elden ele verilmemesi pratiği de değişmeyenler arasında sayılabilir. Mezar kazma işi mahallelerde işi bilen komşular tarafından yerine getirilirken Samsun merkezde bu işlem Büyükşehir Belediyesi'nin personelleri tarafından ifa edilmektedir. Mezar taşları üzerine yazılan özlü sözler ya da şiirsel ifadelerin de geçmişe nazaran azaldığını ifade edebiliriz. Geçmişte ölen kişinin ölüm nedeni, vasiyeti, ölümle ilgili nasihatler mezar taşında yer alırken, günümüzde daha çok ölen kişinin ad1-soyadı, doğum ve ölüm tarihleri ile ElBâki Hüvel-Bâki ifadesinin Arap harfleriyle yazıldığı metinlerin mezar taşlarında yer aldığı görülmektedir. Samsun'da ölünün yakınları mezarın her daim temiz ve düzenli olmasına son derece dikkat ederler. Özellikle arife günleri mezar üzerindeki yabani otların temizlenmesi, kurumuş ağaç dallarının kesilmesi, mezara su dökülmesi gibi uygulamalar büyük 272 bir özenle yerine getirilir. Değişmeyen unsurlardan biri de ölünün anılmasına yönelik belirli günlerinde yapılan dinsel uygulamalardır. Yine mezar ve mezarlık ziyaretleri de belirli günlerde yerine getirilmektedir. $\mathrm{Bu}$ günler daha çok arife günleri ve kısmen de bayram ve cuma günleridir. Kefen parasının önceden hazırlanarak bir kenara konulması konusunda kırsalda yaşayan insanların daha istekli olduğunu belirtmekte yarar vardır. Cenaze evinde yemek pişirilmeyip komşular tarafından bu işin yerine getirilmesinde mahallelerde yaşayan insanların daha duyarlı olduğunu söyleyebiliriz. Ölünün arkasından yas tutma geleneğinin de sürdürüldüğünü ifade edebiliriz.

Ölüm âdetlerinin değişmeyen unsurlardan biri cenazenin tabutsuz bir biçimde (yalnız kefen ile) defnedilmesidir. Yeni Tip Koronavirüs (Kovid-19) nedeniyle ölenlerin büyükşehirlerde -özellikle İstanbul'da- gerekli tedbirler alınarak tabutla gömülmelerine karşın Samsun yöresinde genellikle kefenle defnedildiği görülmektedir. Ancak yurt dışında Kovid-19 nedeniyle ölenlerin cenazeleri tabutla birlikte gömülmektedir. Bahse konu virüsün diğer insanlara bulaşma riskinin en aza indirilmesi amaciyla cenazenin yıkandıktan hemen sonra öğle ve ikindi namazlarını beklemeden de defnedilmesi değişimin bir göstergesi olarak değerlendirilebilir. 
Yine Sağlık Bakanlığı Koronavirüs Bilim Kurulunun tavsiyesi üzerine ölünün yakınlarını teskin etmek ve onların acılarına ortak olmak gayesiyle yapılan taziye geleneğine de ara verilmiştir. Bu süreçte cenaze akşamı cenaze evinde toplanılması, cenazenin ardından yedi, kırk ve elli ikinci gece ölüyü anma ritüellerinin icrası gibi dinî pratikler de terk edilmiş; bunun yerini cenaze sahiplerinin ve yakınlarının kendi evlerinde Kur'an okumaları, hatim indirmeleri yahut 1smarlama olarak din görevlilerine bu görevi tevcih etmeleri gibi uygulamalar almıştır. Yine bu süreçte taziyelerin ya telefon edilerek ya da sosyal medya araçları -facebook, twitter gibiüzerinden mesaj yayınlayarak sunulduğunu ve belediyelerin cenaze hizmetlerine -taziye çadırı kurma, pide-ayran ikram etme gibi uygulamalara- son verdiğini de belirtmekte yarar vardır. Bu uygulamaların ne kadar süreceğini, ne kadarının kalıcı olacağını ve ölüm âdetleri bağlamında yeni bir geleneğin inşasına yol açacağını da zaman içerisinde göreceğiz.

\section{Kaynakça}

1. Yazılı Kaynaklar

Aktaş, Ali Osman. Avut Köyü'nün Halkbilimi Açısından İncelenmesi. Samsun: Ondokuz

Mayıs Üniversitesi, Sosyal Bilimler Enstitüsü, Yüksek Lisans Tezi, 2007.

Arat, Reşit Rahmeti. Kutadgu Bilig I- Metin. Ankara: TDK Yayınları,1991.

Atalay, Besim. Divânü Lügât-it-Türk. C. I-IV. Ankara: TDK Yayınları, 1998.

Campbell, Joseph. İlkel Mitoloji, çev. Kudret Emiroğlu. Ankara: İmge Kitabevi, 1992.

Ergin, Muharrem. Dede Korkut Kitabı. C. I, Ankara: TDK Yayınları, 2008.

Ergin, Muharrem. Orhun Abideleri, İstanbul: Boğaziçi Yayınları, 2012.

İnan, Abdülkadir. Eski Türk Dini Tarihi, İstanbul: Milli Eğitim Basımevi, 1976.

İnan, Abdülkadir. Tarihte ve Bugün Şamanizm Materyaller ve Araştırmalar, Ankara:

Türk

Tarih Kurumu Yayınları, 2015.

Jones, Constance. Huzur İçinde Yatsın - Ölüme Dair Her Şey, çev. Mehmet Gürsel, İstanbul:

Dharma Yayınları, 2004.

Kafesoğlu, İbrahim. Eski Türk Dini. Ankara: Kültür Bakanlığı Yayınları, 1980.

Kocasavaş, Yıldız "Türkçe'nin Tarihî Dönemlerinde Ölüm Kavramının İfadesi”. İstanbul

Üniversitesi Edebiyat Fakültesi Türk Dili ve Edebiyatı Dergisi, 29, (2000), 77115. 
Örnek, Sedat Veyis. Anadolu Folklorunda Ölüm. Ankara: Ankara Üniversitesi Dil Tarih Coğrafya Fakültesi Yayınları, 1971.

Örnek, Sedat Veyis. Türk Halk Bilimi, Ankara: Bilgesu Yayınları, 2014.

Özdemir, Cafer. Havza Yöresi Halk Edebiyatı Ürünleri Üzerine Bir Araştırma. Samsun: Ondokuz Mayıs Üniversitesi Sosyal Bilimler Enstitüsü,Yüksek Lisans Tezi, 2003.

Özdemir, Cafer. "Havza İlçesinin Genel Folklorik Yapısı". Uluslararası Sosyal Araştırma Dergisi, 2/7, (2009), 185-206.

Özdemir, Emrah. Samsun İli Havza İlçesi Karga Köyü Monografisi. Ankara: Gazi Üniversitesi Sosyal Bilimler Enstitüsü, Yüksek Lisans Tezi, 2008.

Roux, Jean Paul. Türklerin ve Moğolların Eski Dini. İstanbul: Kabalcı Yayınları, 2002.

Sami, Şemseddin. Kâmûs-ı Türkî. İstanbul: Çağrı Yayınları, 2009.

Sönmez, Filiz. Samsun İli Canik İlçesi Geçiş Dönemi Âdetlerinde Görülen Kültürel

Değişimler. Samsun: Ondokuz Mayıs Üniversitesi Sosyal Bilimler Enstitüsü, Yüksek Lisans Tezi, 2019.

Şişman, Bekir. Samsun Yöresinde Yaşayan Halk İnançları Üzerine Bir İnceleme. Samsun:

274 Ondokuz Mayıs Üniversitesi Sosyal Bilimler Enstitüsü,Yüksek Lisans Tezi, 1994.

Şişman, Bekir. "Dede Korkut Hikâyeleri'nde Ölüm Karşısında Oğuz'un Tavrı". Dede Korkut

Uluslararası Türk Dili ve Edebiyatı Araştırmaları Dergisi, 4/8, (2015), 121-130.

Tokyürek, Hacer. "Eski Uygur Türkçesinde "Ölüm” Kavramı ile İlgili İfadeler". Bilig

Dergisi, 50, (2009), 178-181.

Turan, Osman. Türk Cihan Hâkimiyeti Mefkûresi Tarihi, İstanbul: Ötüken Yayınları, 2009.

Türkçe Sözlük. Ankara: Türk Dil Kurumu, 1983.

2. Elektronik Kaynaklar

URL-1: Sağlık Bakanlığı. Erişim: 23 Mart 2021. https://covid19.saglik.gov.tr/TR66935/genel-koronavirus-tablosu.html

URL-2: World Health Organization Coronavirus disease (COVID-19). Erişim: 23 Mart 2021 https://www.who.int/publications/m/item/weeklyepidemiological-update-23-march 2020.

URL-3: DİB, Diyanet İşleri Başkanlığı. https://diyanet.gov.tr/trTR/Kurumsal/Detay/29423/din-isleri yuksek-kurulundan-cenaze-namazive-defin-islemleriyle-ilgili-aciklama. Erişim: 4 Kasım 2020.

\section{Sözlü Kaynaklar}




\begin{tabular}{|c|c|c|c|c|c|c|}
\hline & Ad1 Soyadı & $\begin{array}{c}\text { Doğum } \\
\text { Yeri }\end{array}$ & $\begin{array}{c}\text { Doğum } \\
\text { Tarihi }\end{array}$ & Mesleği & $\begin{array}{l}\text { Eğitim } \\
\text { Durumu }\end{array}$ & $\begin{array}{c}\text { Görüşme } \\
\text { Tarihi }\end{array}$ \\
\hline K 1 & $\begin{array}{l}\text { Yakup } \\
\text { CANİKLI }\end{array}$ & Çarşamba & 1964 & $\begin{array}{l}\text { Serbest } \\
\text { meslek }\end{array}$ & İlkokul & 13.07.2019 \\
\hline K 2 & $\begin{array}{l}\text { Gülahmet } \\
\text { OFLAZ }\end{array}$ & Asarcik & 1935 & Emekli & İlkokul & 16.08 .2019 \\
\hline K3 & $\begin{array}{l}\text { Emine } \\
\text { DÜZENLI }\end{array}$ & $\begin{array}{l}\text { Ondokuz } \\
\text { Mayıs }\end{array}$ & 1955 & $\begin{array}{l}\text { Ev han1- } \\
\text { m1 }\end{array}$ & İlkokul & 10.08 .2019 \\
\hline K 4 & $\begin{array}{l}\text { Mahmut } \\
\text { TOPRAK }\end{array}$ & Ayvacık & 1966 & Çiftçi & Ortaokul & 26.07.2019 \\
\hline K 5 & $\begin{array}{l}\text { Ethem } \\
\text { GÜR }\end{array}$ & Salıpazarı & 1959 & Çiftçi & Okur yazar & 03.08.2019 \\
\hline K 6 & $\begin{array}{l}\text { Davut } \\
\text { ŞİSMAN }\end{array}$ & Canik & 1959 & Muhtar & İlkokul & 06.08 .2019 \\
\hline K 7 & $\begin{array}{l}\text { Cemal } \\
\text { BAYRAK- } \\
\text { TAR }\end{array}$ & Canik & 1943 & Emekli & İlkokul & 06.08.2019 \\
\hline K 8 & $\begin{array}{l}\text { Hatice } \\
\text { ESEN }\end{array}$ & Tekkeköy & 1956 & $\begin{array}{l}\text { Ev han1- } \\
\text { mi }\end{array}$ & İlkokul & 17.07.2019 \\
\hline K9 & $\begin{array}{l}\text { Fidan } \\
\text { ÇAKICI }\end{array}$ & $\begin{array}{l}\text { Ondokuz } \\
\text { Mayıs }\end{array}$ & 1964 & $\begin{array}{l}\text { Ev han1- } \\
\text { m1 }\end{array}$ & Ortaokul & 10.08 .2019 \\
\hline K 10 & $\begin{array}{l}\text { Sevgi KÖK- } \\
\text { SAL }\end{array}$ & Vezirköprü & 1956 & $\begin{array}{l}\text { Ev han1- } \\
\text { m1 }\end{array}$ & İlkokul & 25.08 .2019 \\
\hline K 11 & $\begin{array}{l}\text { Raif } \\
\text { ALVER }\end{array}$ & Terme & 1954 & Çiftçi & Ortaokul & 04.09 .2019 \\
\hline
\end{tabular}




\begin{tabular}{|c|c|c|c|c|c|c|}
\hline K 12 & $\begin{array}{l}\text { Resmiye } \\
\text { AKSOY }\end{array}$ & Ladik & 1936 & $\begin{array}{l}\text { Ev han1- } \\
\text { m1 }\end{array}$ & Okur yazar & 26.01 .2020 \\
\hline K 13 & $\begin{array}{l}\text { Temel } \\
\text { KILIÇ }\end{array}$ & Atakum & 1956 & Emekli & İlkokul & 31.08 .2019 \\
\hline K 14 & $\begin{array}{l}\text { Melahat } \\
\text { ŞEKER }\end{array}$ & Bafra & 1943 & Emekli & Okur yazar & 26.08 .2019 \\
\hline K 15 & $\begin{array}{l}\text { Hikmet } \\
\text { KOCAKEL }\end{array}$ & İlkadım & 1962 & Çiftçi & İlkokul & 20.08 .2019 \\
\hline K 16 & $\begin{array}{l}\text { Muharrem } \\
\text { KOCAKEL }\end{array}$ & İlkadım & 1950 & Emekli & İlkokul & 20.08 .2019 \\
\hline K 17 & $\begin{array}{l}\text { Mustafa } \\
\text { CIVELEK }\end{array}$ & İlkadım & 1959 & Çiftçi & Okur yazar & 20.08 .2019 \\
\hline K 18 & $\begin{array}{l}\text { Sefer CÖ- } \\
\text { MERT }\end{array}$ & Kavak & 1946 & Emekli & İlkokul & 27.08 .2019 \\
\hline K 19 & $\begin{array}{l}\text { Tülay KA- } \\
\text { PUSUZ }\end{array}$ & Bafra & 1976 & $\begin{array}{l}\text { Ev han1- } \\
\text { m1 }\end{array}$ & Lise & 26.08 .2019 \\
\hline K 20 & $\begin{array}{l}\text { Ahmet } \\
\text { DEMIR }\end{array}$ & Alaçam & 1959 & Çiftçi & İlkokul & 25.08 .2019 \\
\hline K 21 & $\begin{array}{c}\text { Mesut } \\
\text { YAZICI }\end{array}$ & İlkadım & 1995 & $\begin{array}{l}\text { Gassal- } \\
\text { İmam }\end{array}$ & Üniversite & 16.11 .2020 \\
\hline
\end{tabular}

